\title{
Resistência, necropolítica e fantasias de vingança: Bacurau (2019), de Kleber Mendonça Filho e Juliano Dornelles
}

\author{
Carolin Overhoff Ferreira ${ }^{1}$ \\ José Lingna Nafafé2
}

\footnotetext{
${ }_{1}^{1}$ Professora Associada-Livre Docente do curso de História da Arte da Unifesp. É autora de Introdução brasileira à teoria, história e critica das artes (2019), Decolonial Introduction to the theory, history and criticismo of the arts (2019), Cinema português - Aproximações à sua história e indisciplinaridade (2013), Identity and difference - Postcoloniality and transnationality in Lusophone films (2012), Diálogos Africanos - um Continente no Cinema (2012) e Vom Töten alter Wunden - neue Tendenzen in der Dramatik Lateinamerikas (1999). Organizou os livros O cinema português através dos seus filmes (2007 e 2014), Dekalog - On Manoel de Oliveira (2008), Terra em Transe - Etica e Estética no Cinema Português (2012), Manoel de Oliveira - Novas perspectivas sobre a sua obra (2013) e África - um continente no cinema (2014).

Email: carolinoverferr@yahoo.com

2 Professor Associado da Universidade de Bristol. Foi diretor do mestrado em "Black Humanities" (Humanidades Negras). É autor de Lourenço da Silva Mendonça and the Black Atlantic Abolition Movement in the Seventeenth Century (no prelo) e Colonial Encounters: Issues of Culture, Hybridity and Creolisation, Portuguese Mercantile Settlers in West Africa. Publicou diversos capítulos e artigos sobre cultura e história africana e lusófona, e imigração, entre eles sobre o cineasta guineense Flora Gomes, em periódicos como Portuguese Studies, European Journal of Social Theory, Hispanic Research Journal etc.

Email: jose.lingnanafafe@bristol.ac.uk
} 


\title{
Resumo
}

Bacurau (2019) de Kleber Mendonça Filho e Juliano Dornelles, foi o filme brasileiro mais polêmico de 2019. Estreou no Festival de Cannes 2019, onde obteve o Prêmio especial do Júri, e depois ganhou mais distinções nacionais e internacionais. Foi elogiado e criticado como filme de resistência contra o atual governo de Jair Bolsonaro, seu discurso sexista, racista e homofóbico. Este artigo procura analisar três aspetos centrais do filme: 1) a maneira como se dá essa resistência contra os invasores norteamericanos que utilizam o povoado de Bacurau para um videogame real, valendo-se de sua população como alvos vivos; 2) o emprego da necropolítica, que possui historicamente uma dimensão mais violenta no Brasil devido ao trafico de escravizados e à escravidão, e que está atrás da venda da vila pelo prefeito Tony Júnior; e 3) a fantasia de vingança relativamente a essa opressão e à qual o filme dá expressão por meio de um banho de sangue violento quando o povoado se defende contra os invasores. O maior objetivo deste artigo e da análise desses aspetos consiste em compreender se o filme contribui para o debate sobre racismo no Brasil, no sentido de promover a discussão acerca da necessária decolonização das mentes para enfrentar o fundamental problema da desigualdade nacional e de seu ainda vigente poder colonial, ou se é apenas uma válvula de escape para as frustrações políticas, oferecendo um momento catártico muito pontual aos espectadores.

Palavras-chave: Bacurau; cinema brasileiro; cinema contemporâneo; resistência; necropolítica

\section{Abstract}

Bacurau (2019), by Kleber Mendonça Filho and Juliano Dornelles, was the most controversial Brazilian film of 2019. It debuted at the Cannes Festival 2019, where it won the Special Jury Prize, and later won more national and international distinctions. It was praised and criticized as a film that promotes resistance against the current administration of Jair Bolsonaro, its sexist, racist, and homophobic discourse. This article seeks to analyze three central aspects of the film: 1) the way in which this resistance occurs against the American invaders who use the village of Bacurau for a real videogame with its population as living targets; 2) the use of necropolitics, which historically had a violent dimension in Brazil due to the trafficking of enslaved people and slavery, and which is behind the sale of the village by its mayor Tony Júnior; and 3) the fantasy of revenge for this oppression, to which the film gives expression through a bloodbath when the town defends itself against the invaders. The main objective of this article in analyzing these aspects is to understand whether the film contributes to the debate on racism in Brazil by promoting a debate about the necessary decolonization of the minds so as to face the fundamental problem of inequality given the still existing colonial power, or if it is just a vehicle for the current political frustrations, offering viewers a momentary cathartic experience.
\end{abstract}

Keywords: Bacurau; Brazilian cinema; contemporary cinema; necropolitics 


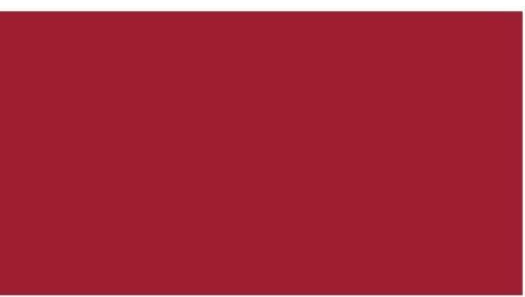

\section{Introdução}

Quando assistimos Bacurau (2019) de Kleber Mendonça Filho e Juliano Dornelles, estreado em 2019, pela primeira vez no cinema, saímos bem desapontados. A discussão na mídia acerca de suas dimensões política - resistência - e estética mistura inteligente de gêneros em filme autoral - havia criado grandes expectativas, mas a história do povoado no nordeste sendo atacado por gringos para eliminá-los parecia pouco sofisticada. Ao rever Bacurau agora, em junho de 2020, em plena pandemia do coronavírus, o vimos sob o impacto da morte violenta do afro-americano George Floyd, assassinado sem o mínimo de humanidade por um policial nos Estados Unidos, no dia 25 de maio. A leitura que dele fazemos ganhou novos contornos.

$O$ asfixiamento sem piedade de George Floyd, filmado por uma jovem mulher corajosa durante longos 8 minutos e 48 segundos, que tornou inegável essa prática policial recorrente, levou a protestos antirracistas em mais de 2.000 cidades, primeiro na América do Norte e depois na Europa, acompanhados por enfrentamentos com a polícia. Desde maio 2020 têm sido arrancadas estátuas de escravagistas e de outros representantes do imperialismo e colonialismo em vários países, e iniciaram-se reformas exigidas há décadas para conter a violência do Estado por meio da polícia nos EUA. No Brasil, a discussão da supremacia e dos privilégios brancos, apesar dos incontáveis assassinatos de afrodescendentes e seu encarceramento maciço, não despertou a mesma revolta maciça nas ruas. ${ }^{3}$ Pode-se especular que isso se deve à tradição de silenciamento do racismo e de seu pouco reconhecimento no debate público, ambos baseados no falso mito da democracia racial, que conseguiu apagar e abafar a violência do Estado, praticada contra a população afrodescendente desde a abolição da escravatura através da Lei Aurea de 1888 até hoje. Vale lembrar que no Brasil a legislação tentou restringir ao longo de décadas a participação afrodescendente na sociedade, e que a reversão dessas leis foi conquistada com muita luta, porém sem que tenha conseguido eliminar o racismo estrutural profundamente enraizado. ${ }^{4}$ Após a morte

\footnotetext{
${ }^{3} \mathrm{Em} \mathrm{2018,75,7 \%}$ das vítimas de homicídios no Brasil eram negras, um aumento de 11,5\%. Dados de https://brasil.elpais.com/brasil/2020-08-27/numero-de-homicidios-de-pessoas-negras-cresce-115-emonze-anos-o-dos-demais-cai-13.html.

${ }^{4}$ Um pequeno e incompleto histórico demonstra a implementação do racismo estrutural brasileiro e a difícil passagem dos afrodescendentes de objeto para sujeito de lei: "Durante quase quatrocentos anos o negro foi objeto útil de compra e venda, sujeito à hipoteca. Conforme classificação de Teixeira de Freitas, Consolidação das Leis Civis (1858), os escravos pertenciam à classe dos bens móveis, ao lado dos semovente." (PRUDENTE, 1988) O Código Criminal (art. 179) definia a redução de pessoa livre à escravidão como crime, mas as disposições Filipinas foram mantidas para garantir os interesses econômicos dos senhores. Em decreto de 1837 foram proibidos a frequentarem escolas: "A reforma da instrução primária realizada em 1837 na província do Rio de Janeiro, por exemplo, proibia a frequência à escola daqueles que sofressem de moléstias contagiosas, dos escravos e dos pretos africanos, ainda que livres e libertos." (ALMEIDA et al., 2016). Em 1850 a "lei de terras" impedia compra de terreno. O Decreto 847 de "Vadios e Capoeiras" proibiu expressões culturais e religiosas afro-brasileiras, levando ao encarceramento. Por outro lado, em 1911 foram garantidas terras e educação aos imigrantes
} 
de George Floyd aumentaram debates e lives, mas não houve adesão sólida da população aos protestos como aconteceu nos EUA. ${ }^{5}$

Com esse novo contexto surgiu a pergunta central para o nosso estudo se 0 racismo não seria um dos temas principais em Bacurau (2019), assunto que devido ao enfoque na dimensão de resistência contra o atual governo de Jair Bolsonaro passou sem comentário na imprensa. Suspeitamos, no entanto, que a questão é tão velada no filme como a é no contexto sociopolítico brasileiro, em que tanto o racismo estrutural como a violência do Estado contra a população afrodescendente são historicamente negados, nomeadamente no governo bolsonarista que as incentiva através de um discurso racista, além de sexista e homofóbico. ${ }^{6}$ Será que nossa nova leitura com enfoque no racismo seja apenas projeção, como eram as leituras dos críticos na altura da estreia?

Lembramos rapidamente a sinopse do filme. Em um futuro próximo, uma jovem mulher mestiça, Teresa, retorna para sua vila, Bacurau, no interior de Pernambuco. Ela volta para atender o funeral de sua avó, Carmelita, uma matriarca negra, organizado pelo seu pai, o professor negro Plínio. Após esse rito em comunidade, com participação de todo o povoado, coisas estranhas começam a acontecer que colocam as pessoas em alerta: um casal de motoqueiros gaúchos aparece, chamando atenção à falta de sinal de internet. Cavalos de uma das pequenas fazendas surgem em bando à noite e, quando são retornados por dois jovens, eles descobrem que todos os seus habitantes foram assassinados de forma brutal. Os motoqueiros interceptam e matam os jovens para que a informação não chegue até Bacurau. Saberemos depois que o prefeito do município autorizou um esquema internacional, executado pelo casal gaúcho, que tirou a vila do mapa para que sirva como playground de um grupo de turistas estadunidenses, possibilite que vivam seu desejo perverso de supremacia branca, e façam um videogame que migrou do virtual para o real: caçar e matar os nativos. Quando Pacote, um jovem que tem um namorico com Teresa e atua como justiceiro na tradição do

europeus (Lei 9.081) e em 1934 é incluída a ideia da Eugenia na Constituição, visando o branqueamento da nação. Ao mesmo tempo, traz pela primeira vez o direito ao voto à população afrodescendente, exclusive aos analfabetos. Mas já em 1937 o órgão que articularia a luta por mais direitos e igualdade, a Frente Negra, é proibido. A legislação que tentou contornar essa discriminação histórica e estrutural é recente: a Lei 7.716, chamada Lei Caó, de 1989, declara racismo crime, o artigo 140 do código penal regulamenta injúria racial e a Lei 12.288 de 2010 instituiu o Estatuto da Igualdade Racial.

5 Talvez porque o país tenha no momento outra agenda política, relacionada aos 44 pedidos de impeachment contra o atual presidente Jair Bolsonaro e à cada vez menos possível cassação da chapa dele devido à manipulação das eleições por fake news. Um resumo do processo em curso pode ser encontrado, por exemplo, para não usar um veiculo de imprensa nacional, na BBC: https://www.bbc.com/portuguese/brasil-52824346.

6 Para uma análise crítica acerca do discurso de Bolsonaro veja https://www1.folha.uol.com.br/poder/2020/01/veja-falas-preconceituosas-de-bolsonaro-e-o-que-diz-alei-sobre-injuria-e-racismo.shtml. 
cangaço ${ }^{7}$, encontra seus amigos mortos e descobre também a matança na fazenda, ele pede ajuda a outro homem ambíguo, mas procurado pela polícia. Esse outro cangaceiro contemporâneo, de nome Lunga, possui um projeto político mais definido: enfrentou o poder local quando cortou a água encanada. Desde então, teve que abandonar a vila e vive com mais dois amigos na barragem local que deixou de funcionar. Homem de gênero fluido, ${ }^{8}$ organiza então a defesa de Bacurau e mata os atacantes gringos em uma carnificina gráfica. No desfecho vemos o povoado unido e vitorioso. Livra-se do prefeito, que é amarrado - nu, com apenas uma máscara na cabeça - em um burro e levado sertão afora. O chefe do grupo supremacista norte-americano, um alemão, é, por sua vez, enterrado vivo em uma espécie de bunker. Antes disso, as cabeças cortadas dos outros invasores foram expostas em frente da igreja, em uma citação e ressignificação da clássica foto das cabeças cortadas e mumificadas do mais famoso cangaceiro, Lampião, sua amante Maria Bonita, e alguns de seus jagunços.

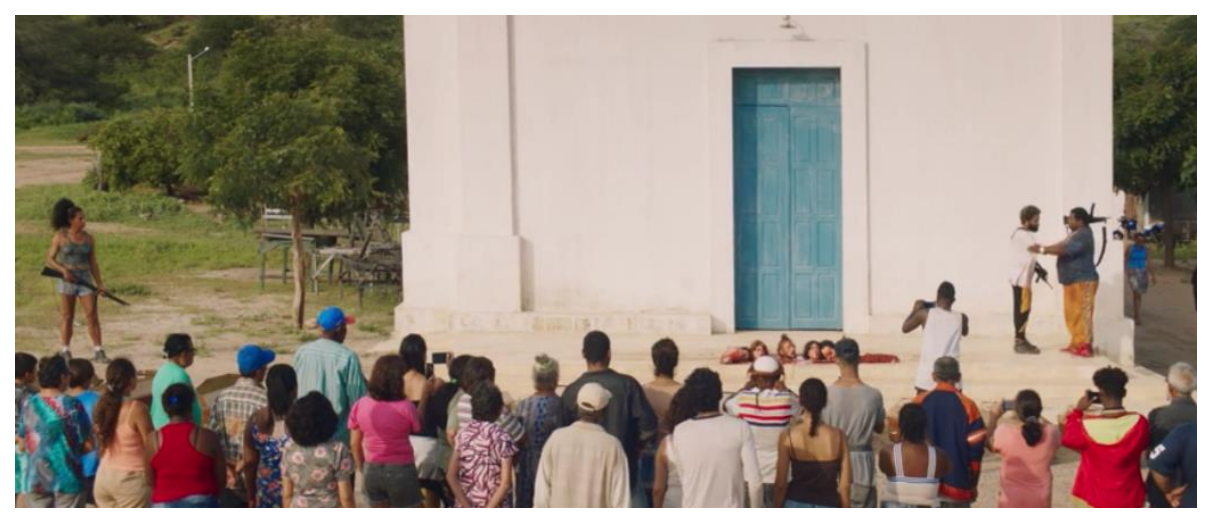

Figura 1: Exposição das cabeças dos gringos invasores no final de Bacurau.

Fonte: Vitrine Produções.

O cangaço como "banditismo social" no final do século XIX e início do XX é visto como sendo ambíguo na literatura, porque possuía duas faces, tendo sido tanto uma

\footnotetext{
${ }^{7} \mathrm{O}$ cangaço foi um fenômeno de banditismo violento na sociedade brasileira novecentista como protesto diante das injustiças sociais no nordeste, que havia perdido sua importância ainda durante a colônia com o deslocamento da capital para o sudeste, na cidade do Rio de Janeiro. Durante o Império a situação não melhorou, e a população local nordestina ficou insatisfeita, principalmente diante do poder dos latifundiários que se apropriavam das melhores terras, explorando a população no cultivo delas, sobretudo na pecuária.

8 Os diretores queriam inicialmente que fosse uma mulher trans, mas o ator, Silvero Pereira (JUCÁ, 2019), declinou essa possiblidade e deu outra caracterização. $O$ ator explica: "O que mais interessa é algo que está no filme inteiro. É que a comunidade não se importa se uma mulher trans vive com dois homens, se a médica vive com outra mulher, que por sua vez se relaciona com um michê. A comunidade não se incomoda com absolutamente nada, então porque os espectadores iriam se incomodar com a sexualidade de Lunga?" (PEREIRA apud JUCÁ, 2019). Como dito anteriormente, não temos tanta certeza que o filme é tão isento sobre as relações sexuais como o ator sugere. Seria bom se alguém dedicasse um estudo a isso.
} 
vertente de resistência contra a canga dos latifundiários - ou seja, o jugo carregado pela população pobre, cabocla e afrodescendente, e assim uma defesa contra as injustiças sociais -, como parte da opressão e apenas outra forma de violência, seja através de pilhagens, assassinatos e estupros, cometidos pelos cangaceiros independentes ou os jagunços a mando dos oligarcas:

Ele nasce da revolta diante da desigualdade social, mas não se constitui agente transformador. Ele se insere na comunidade, eventualmente rouba dos ricos e dá alguma coisa aos pobres, mas monta uma rede de cumplicidade em geral baseada tanto no terror como na troca de favores. Funcionava um pouco como os atuais chefões do tráfico de drogas ou os capi mafiosos. Protege, presta favores, beneficia a comunidade. Mas ai de quem não se submeter às suas regras e desejos. O cangaceirismo entra, como hoje o crime organizado e tráfico, onde o Estado não entrava. Ele ocupava essa fresta do Estado, de maneira ostensiva, até que acabou, com o declínio do coronelismo, ao qual prestava seus bons serviços. (ORICCHIO, 2005: 52)

Degolar era uma honra praticada tanto pelos cangaceiros como pelos seus opositores, os volantes e policiais a serviço dos latifundiários e do governo. Quem matava o adversário era "considerado herói da sangrenta façanha" e podia lhe cortar a cabeça (MELLO, 2018: 20). As cabeças de Lampião e seus jagunços foram expostas após o assassinato deles pela polícia em 1938, no contexto de um "mundo de despotismos incríveis" (MELLO, 2018: 42). Na época "as condições naturais (...), exacerbadas pelo mandonismo aldeão e seus instrumentos de maior valia, a guerra e a vingança privadas, [davam] vida a uma cultura que inculcava a violência, [e] o banditismo grassou de alto a baixo em nosso território" (MELLO, 2018: 56). 


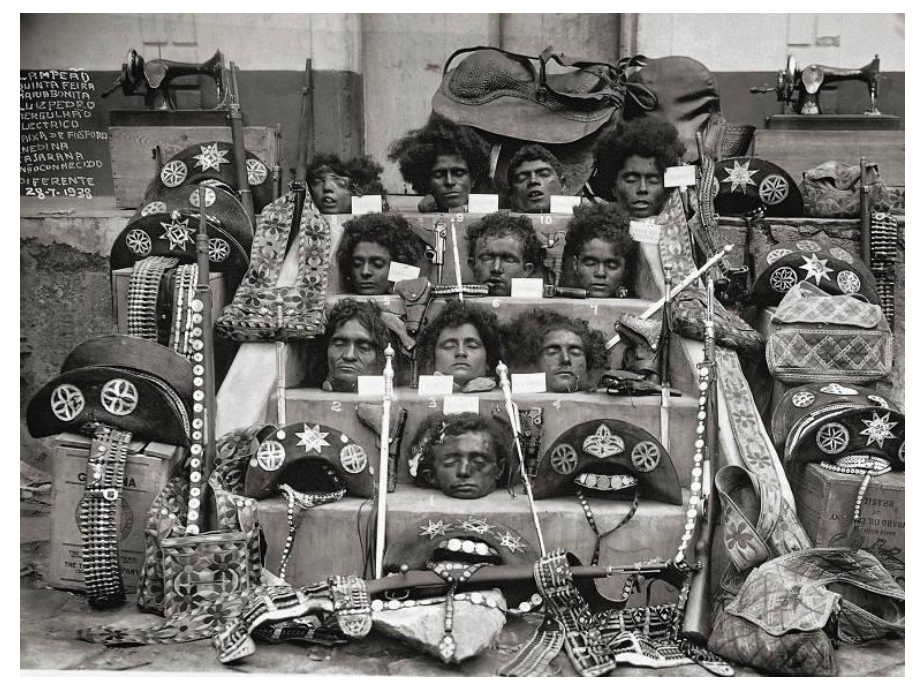

Figura 2: Cabeças cortadas do bando de Lampião.

Fonte: https://wikimedia.common.org.

A violência no filme dialoga obviamente com o cangaço histórico. Mas enquanto o Estado matou os cangaceiros, Bacurau (2019) cita o gesto de decapitação, invertendo o acontecimento histórico: agora é o povoado marginalizado e vitimizado que degola os representantes do poder, nomeadamente os turistas gringos que pagaram o político brasileiro para poder caçá-los. Reage, portanto, com violência contra a violência do Estado, procurando justiça social. Isso não ocorre no exemplo dado por Oriccho (2005) em relação ao tráfico de drogas, embora é preciso levar em consideração que a subalternização na favela e o tráfico de drogas são reflexos de uma longa história de marginalização da população descendente dos escravizados e do racismo institucional. Lembrar o fim do cangaço com um gesto que o ressignifica procura oferecer uma visão sobretudo positiva dele como resistência, como defesa contra a necropolítica do Estado.

Embora seja uma inversão, esse ato brutal e simbólico não deixa de fazer parte da ambiguidade da violência nacional. Não surpreende que a violência justiceira como parte necessária da resistência à violência do Estado brasileiro foi o tema central abordado pelos críticos de cinema em suas resenhas. Como Aquarius (AQUARIUS, 2016), produção anterior de Kleber Mendonça Filho, Bacurau (2019) foi lido no contexto político e interpretado ou como filme visionário (BENTES, 2019), ou como propaganda da esquerda (MAGNOLI, 2019). Essa vez o pano de fundo da discussão não foi o impeachment da presidente Dilma Rousseff, em 2016 (cf. FERREIRA 2017), mas o governo atual e as ações e o discurso de seu presidente contra a população indígena, negra e LGBT+. Novamente as críticas eram ou contra, ou a favor, tecendo elogios ao 
diagnóstico de uma necessária resposta à altura da violência verbal e do espírito miliciano bolsonarista de um lado, ou fazendo duras críticas ao maniqueísmo do filme de outro. Enquanto uns viam o maniqueísmo como parte de uma estratégia didática (ARAÚJO, 2019b; NUNES, 2019) para falar da revolta dos marginalizados unidos, válido para o cenário nacional e internacional, outros o interpretaram como visão simplificadora do imperialismo norte-americano (MAGNOLI, 2019). A estética do filme foi vista na mesma chave: a mistura de gêneros - filme B, faroeste, nordestern ${ }^{9}$, ficção científica e filme de terror - ganhou tanto comentários favoráveis (BENTES, 2019; NUNES, 2019; PITANGA, 2019), quanto críticas depreciativas acerca da suposta imitação de padrões hollywoodianos, sobretudo de Quentin Tarantino (MAGNOLI, 2019) e sua estetização da violência, fascinação com a "subcultura e subliteratura". Criticou-se, ainda, a linguagem televisiva e a falta de atenção à cultura regional do sertão (FORLIN, 2019).

Em um país que radicalizou, desde o impeachment em 2016, cada vez mais suas posições políticas entre direita/ultradireita e esquerda - retomando a ideia da existência de "dois demônios"10 implementada durante a ditadura militar (1964-1985), agora em termos de uma esquerda corrupta e uma direita militarista -, o que pensar dessa polarização politizada na leitura do terceiro longa de Kleber Mendonça Filho? Será que Bacurau (2019) é "um testemunho de nossa miséria intelectual, ou, mais precisamente, da extinção de qualquer traço de vida inteligente na esquerda brasileira" (MAGNOLI, 2019)? Ou é "um filme claro e direto", "a síntese do Brasil brutal” (BENTES, 2019), de uma "clareza alegórica" (ARAÚJO, 2019a), sendo que "é da ordem da evidência que 'Bacurau' é um filme sobre resistência e de resistência” (ARAÚJO, 2019b)?

Para responder a essas indagações, perguntaremos se a narrativa sobre a defesa de Bacurau contra os turistas gringos invasores, que supostamente inverte o mote dos faroestes clássicos - cowboys contra nativos - em chave melodramática,

\footnotetext{
${ }^{9} \mathrm{O}$ nordestern é um desdobramento do gênero americano western no Brasil em filmes sobre o cangaço: "O neologismo Nordestern é uma criação do pesquisador potiguar-carioca, Salvyano Cavalcanti de Paiva (1923-2000). Há quem o atribua, também ao crítico baiano-carioca, Antônio Moniz Viana. (...) Em Revisão Crítica do Cinema Brasileiro (...) (1963), ele escreve: 'Se o tema da aventura esteve presente na obra de Humberto Mauro e em outras experiências do antigo cinema brasileiro, sua definição como gênero de cangaço, hoje habilmente batizado por Salvyano Cavalcanti de Paiva como nordestern, aparecia somente em 1953, no polêmico filme de Lima Barreto'."(CAETANO, 2005: 11)

${ }^{10}$ Edson Teles (2018: 29) explica que "os militares utilizaram o discurso dos 'dois demônios', cuja tese argumentava sobre a existência de setores radicalizados: os militantes da luta armada e os agentes dos porões da ditadura. Tentava-se igualar a luta de resistência com a barbárie da tortura e dos assassinatos comandados pela cúpula das Forças Armada. Sob esta lógica, autorizava-se o surgimento da ficção de uma posição de consenso, comprada por setores conservadores da oposição, que supostamente reconheceria a história recente do país, mas prioritariamente com o intuito de superar seus excessos." Esse discurso foi replicado na democracia, sugerindo que houvesse dois polos: um que queria lembrar as vítimas de forma revanchista, e outro que queria esquecer violentamente. $\mathrm{E}$ o encontramos nas resenhas dos filmes, confrontando a "ultradireita feroz, caricata, lunática (...) a imagem espelhada de nossa esquerda anacrônica, primitiva e mistificadora" (MIGNOLI, 2019).
} 
vitimizando o povoado, é efetivamente uma narrativa de resistência. Perguntaremos também se, no contexto de nossa sociedade de consumo do capitalismo tardio, o filme usa elementos desse e de outros gêneros cinematográficos para atingir o grande público com um tema político sobre o qual ainda existente poder colonial e a violenta opressão de pobres e marginalizados pelo Estado para os quais a única resposta acaba sendo a violência. Em outras palavras, indagaremos se ao inventar uma narrativa sobre a autodefesa contra o poder maquiavélico dos governantes e uma estética de excesso ${ }^{11}$ o filme procura falar sobre algo que "não é palatável", sendo que no Brasil "resistência causa horror" e Bacurau (2019) "ousa discutir algo bastante incômodo para nossa cultura: o uso da justa violência do oprimido contra a injusta violência do opressor" (ORICCHIO, 2019). ${ }^{12}$

Dada a polarização, nosso objetivo principal consiste em entender em termos antropológicos, cuja "realidade interior e exterior" (SEEL, 2013) Bacurau (2019) de fato reflete, o que e quem ele quer mobilizar, e o que isto diz sobre nós e o nosso atual estado político-cultural, bem como sobre a nossa relação com a violência. Os conceitos chaves para essa discussão provem de diversos campos disciplinares: da filosofia política e da sociologia emprestamos a "biopolítica" (FOUCAULT, 1999; 2000), a "necropolítica" (MBEMBE, 2016), a "supremacia branca", o "racismo" e o "quilombismo" (NASCIMENTO, 2016), o "poder colonial" (QUIJANO, 2006), e a ideia de que "decolonização" é sempre um fenômeno violento (FANON, 2006); da psicologia, a "fantasia de vingança" (HOROWITZ, 2007; GOLDNER et al., 2019); e da estética, dos estudos de cinema e das mídias, a "catarse" (ARISTOTELES, s.d). Abordaremos, para tal, primeiro a narrativa e seus personagens, nomeadamente a composição do povoado e o significado dele, a resistência dele e como essa se desenvolve. Depois entraremos

\footnotetext{
${ }^{11}$ Entendemos como estética de excesso um estilo que amplifica e realça certos elementos - no caso do filme, a violência. Esse tipo de excesso possui uma longa tradição na história das arte, sobretudo desde a contrarreforma, no Barroco, em que servia para aumentar a experiência do espectador no sentido de intensificar seus sentimentos. Na estética contemporânea e do cinema, é discutido nesse contexto, por exemplo, por Alain Badiou (2013).

12 Em 2016, Carolin Overhoff Ferreira escreveu um artigo sobre o segundo filme de Kleber Mendonça Filho, Aquarius (AQUARIUS, 2016) comparando-o com Terra em Transe de Glauber Rocha, onde perguntou se os dois filmes poderiam ser vistos como diagnósticos do Brasil, como isso se dava e o que implicaria. (FERREIRA, 2017). O mote do diagnóstico perpassa também a nossa pergunta sobre as dimensões político-estéticas de Bacurau (2019). Por isso, lembramos rapidamente a definição antropológica do cinema por Martin Seel (2013), que considera que o audiovisual compartilha com qualquer outra forma de arte a possibilidade de enfrentarmo-nos tanto com nós mesmos como com o que nos rodeia. Para o autor, o audiovisual apresenta variações e variantes das nossas vidas e das nossas esperanças acerca dela: "joga com as possibilidades e impossibilidades da experiência e expectativa humanas" (SEEL, 2013: 234). Ver um filme significa ver uma versão alternativa da nossa vida interior e da nossa realidade exterior que nos pode mover e, eventualmente, fazer mover, no sentido de nos fazer sentir, pensar e eventualmente agir conforme seu posicionamento perante o status quo sócio-político (FERREIRA, 2017).
} 
na questão do conflito para pensarmos a violência, a resposta a ela e sua estetização cinematográfica.

\section{Bacurau - o drama da violência \\ Brava gente sertaneja}

Um pássaro bravo do sertão ${ }^{13}$ dá o título ao filme, servindo como analogia para o povo pobre mas resistente que mora nessa vila. Bacurau é, por certo, um povoado cuidadosamente pensado pelos dois cineastas. Por situar a narrativa e seu conflito em um futuro próximo, ele possui algumas características que exageram ou até substituem aquelas que encontraríamos na realidade exterior no atual Nordeste - a ausência do Estado em termos de infraestrutura médica e educacional -, embora a realidade interior - as necessidades e os desejos dos habitantes - não diferem muito. Tanto a vila como os gringos possuem tecnologia de ponta (carros com imagens em LED, celulares e tabletes, uma câmara em formato óvni), mas algumas privações e problemas sóciopolíticos são mais hiperbólicos, como a total negação de água pelo poder público. Ao mesmo tempo, a vila é caracterizada pela diversidade em termos de identidade de gênero e liberdade sexual, e se utiliza de tecnologias menos visíveis, sendo a sua relação com seus ancestrais, bem como os conhecimentos de plantas dois exemplos que marcam a narrativa.

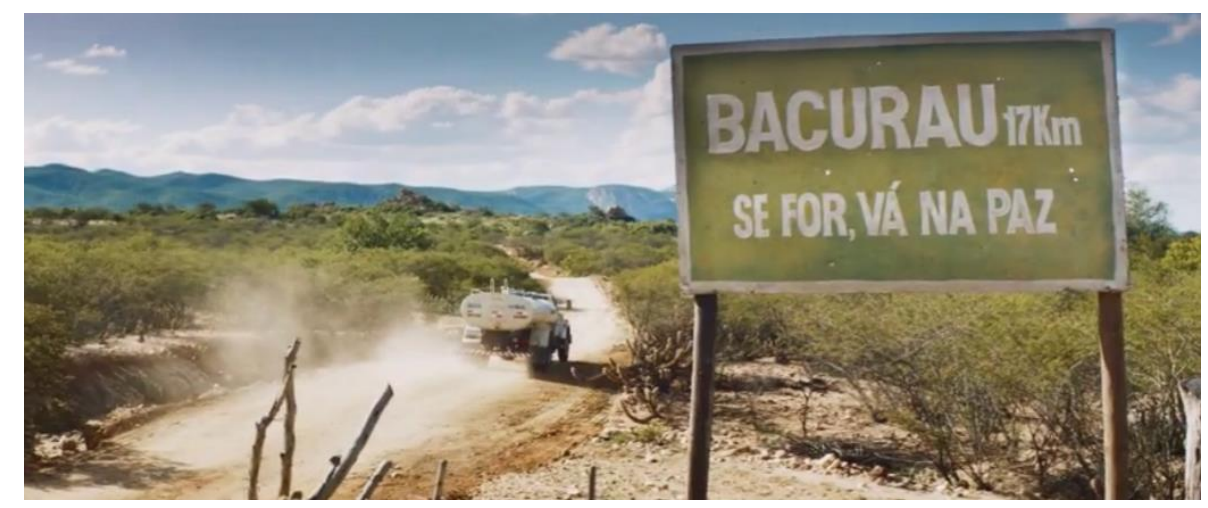

Figura 3: Entrada do povoado em Bacurau. Fonte: Vitrine Produções.

Quem habita então essa vila, que inclui algumas fazendas pequenas e sítios ao redor? O velório é aproveitado para mostrar que em Bacurau moram homens e mulheres

\footnotetext{
${ }^{13}$ A dimensão metafórica do nome Bacurau procura caracterizar o povoado como sendo pequeno, mas valente. A ave mede menos de 30 centímetros, mas suas grandes asas a tornam ágil para caçar insetos à noite.
} 
simples, de todas as faixas etárias, cor de pele, orientação sexual, etc. Juntam-se em comunhão no cortejo de despedida de uma figura homenageada pelo filho. É uma comunidade pobre, parda e negra, de afrodescendentes e caboclos, que se reúne para celebrar um rito que introduz o tema central do filme: a morte. Não por acaso, inicia com uma morte natural, um destino que as circunstâncias políticas - a venda dos habitantes da vila - pretendem alterar de forma mais radical, marcando a população com a morte certa, como acontecia historicamente com os escravizados.

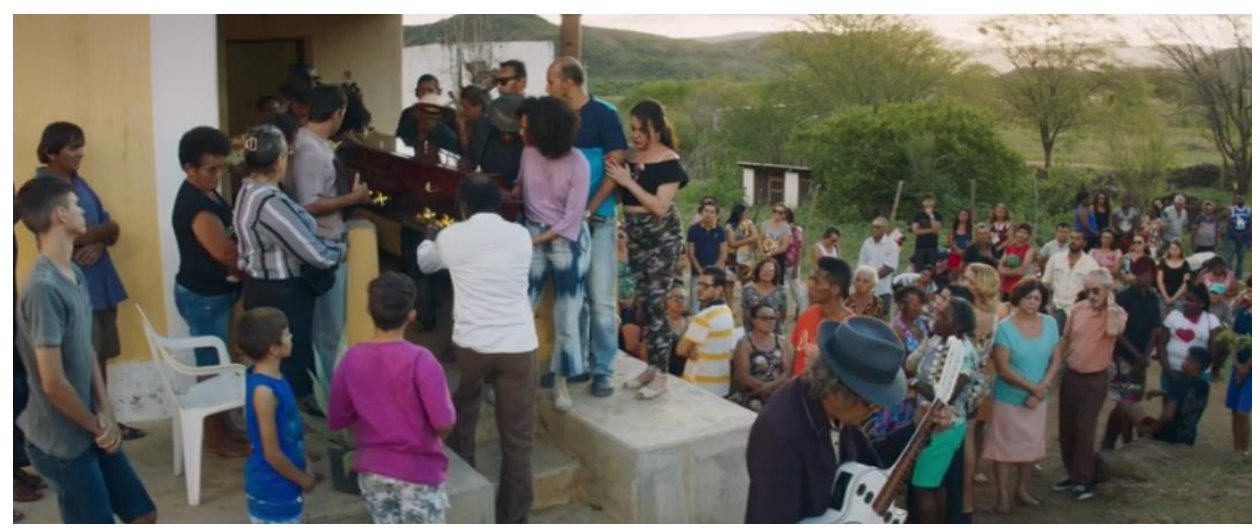

Figura 4: Cortejo para Dona Carmelita.

Fonte: Vitrine Produções.

No dia após o funeral, o filme passa a caracterizar a vila através de seus afazeres cotidianos: tem uma feira, o museu da cidade é aberto, crianças estudam na escola. É ressaltado que, para a vila, cultura e ensino possuem grande importância. Tanto museu (que conta a história do cangaço) como escola são resultado dos esforços comunitários da população e terão papel importante na narrativa como lugares destacados na resistência. O Estado está obviamente ausente, pois nos primeiros minutos do filme já vemos que os governantes deixaram a escola municipal em ruínas. 


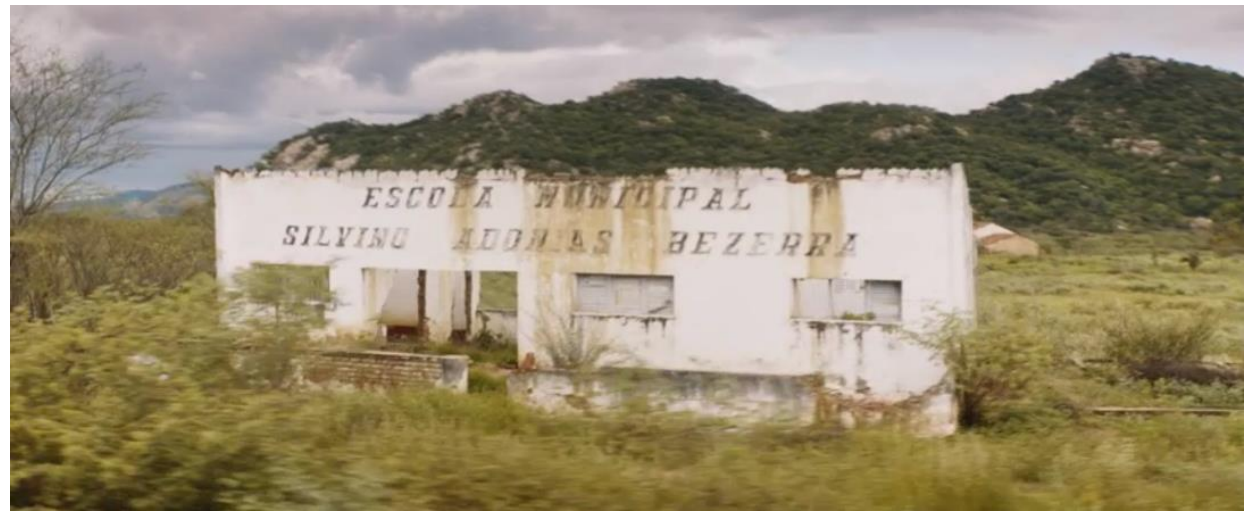

Figura 5: Escola municipal em ruínas.

Fonte: Vitrine Produções.

O povoado conseguiu driblar até certo ponto a escassez material, embora a dependência de doações seja reforçada na visita do prefeito em relação a alimentos, medicamentos e livros. Uma dimensão da modernidade desse lugar pobre e abandonado é justamente a escola, onde se usa tecnologia de ponta para um ensino apaixonado e lúdico até sumir o sinal e o povoado desaparecer do mapa geográfico com o intuito de erradicá-lo. Em outras palavras, o filme faz questão de mostrar que o lugar é moderno e humanista no melhor sentido: leigo, diverso, desconhece racismo ou homofobia e preocupado com educação e cultura, ou seja, justamente tudo o que a ultradireita e o atual governo bolsonarista atacam. Além disso, todos estão conectados ao mundo, possuem celulares e tabletes, e a cobertura de internet parece boa, até os gringos utilizarem a sua supremacia também tecnológica para acabar com os avanços, tanto tecnológicos como humanos, que este lugar simples representa. Em suma, em Bacurau vivem pessoas que, procurando sobreviver dentro do possível, criaram uma comunidade. Há apenas pequenos conflitos, porém, como um todo, é um lugar onde se vive e se deixa viver.

O prefeito, Tony Júnior, cujo nome indica que é filho de alguma linhagem provavelmente oligárquica, o que o destaca das pessoas mais que vivem na vila, é a caricatura clássica de um coronel e político corrupto e interesseiro, isto é, da classe dominante que, no tempo do filme, possui o referido monopólio sobre a água. ${ }^{14}$ Há um pormenor importante que demonstra a consciência da vila em relação aos abusos de

\footnotetext{
${ }^{14}$ Caricatura é modo de dizer, porque, desde o impeachment televisionado da presidente Dilma Rousseff, pode-se dizer que nenhuma caricatura consegue traçar de forma suficientemente grotesca alguns políticos oligarcas que apresentaram suas razões toscas, baseadas no poder da família e da propriedade, alheios de ideias republicanas e democráticas.
} 
seu prefeito. Quando ele chega - e ele é anunciado pela mulher trans por walkie-talkie logo depois de termos conhecido o cotidiano da vila -, todo mundo some e se esconde. Ele descarta livros velhos e aparentemente pouco utilizáveis de um caminhão, deixa alimentos, muitos já com a data de validade vencida, bem como medicamentos de tarja preta. O desprezo desse governante pela educação e pela saúde da população não poderia ser mais visível. No final de sua visita, pega uma das prostitutas e vai-se embora. Ela voltará mais tarde, visivelmente maltratada, mas ninguém faz nada.

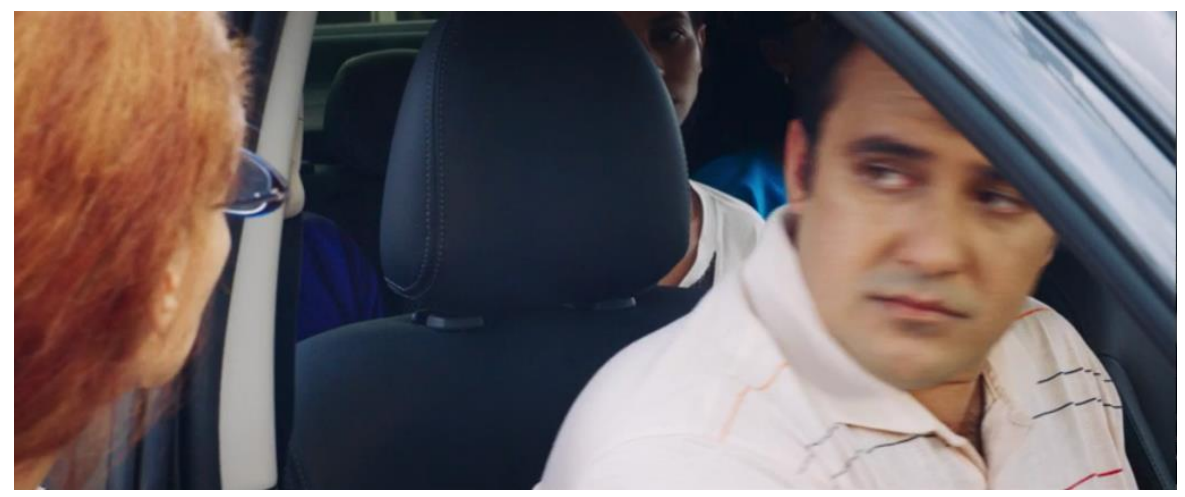

Figura 4: Tony Júnior leva a prostituta Sandra embora contra sua vontade. Fonte: Vitrine Produções.

Se Bacurau foi pensada como habitada pelos brasileiros médios - que são claramente covardes quando ele chega e quando a prostituta retorna -, Tony Júnior é seu político médio - dá migalhas para ficar com o resto. Exagerando ainda mais essa atitude do poder, bem conhecida na realidade, Tony Júnior vendeu a população da vila como antigamente os senhores das fazendas vendiam os escravizados. Só que dessa vez não para trabalharem, mas para serem abatidos como animais.

Ao girar em torno de uma premissa pouco provável porém hiperbólica, a narrativa vitimiza a população por meio de uma estrutura melodramática, aliando o realismo na caracterização do povoado a uma situação de ataque para intensificar o dramatismo e assim aumentar o envolvimento do público, mas aponta também para a covardia dela. Bem nos primeiros minutos sabemos que a vila está sendo privada de água e que Lunga foi o único a oferecer resistência. Teve troca de tiros e ele vive desde então na torre da barragem. A vila claramente despreza o prefeito, mas aceita os livros e os alimentos, afirmando assim sua dependência, não se rebelando contra ela, como o faz Lunga. A única forma de demonstrar seu desagrado consiste em deixar Tony Júnior falar sozinho sobre as próximas eleições. Somente Domingas mostra algum caráter ao enfrentá-lo quando ele sequestra a prostituta. 
Antes do ataque, a maioria dos habitantes é pacífica, ou melhor, passiva, dependendo do ponto de vista. Aqui vale lembrar o filme anterior de Mendonça Filho, Aquarius (AQUARIUS, 2016). É um dos poucos filmes brasileiros que oferece um personagem resistente, cujo papel, não por acaso, foi representado por Sonia Braga, que reencontramos em Bacurau como Domingas (cf. FERREIRA, 2017). ${ }^{15}$ Curiosamente, a narrativa de emancipação de Clara, a crítica de música abastada, se repete em Bacurau (2019). Mas, desta vez, é toda a vila liderada por homens de identidade de gênero não binário que realiza a resistência. Ao contrário de Aquarius (2016), não se trata de uma situação que podemos reconhecer facilmente em nossa realidade, porque em vez de especulação imobiliária, problema universal do capitalismo tardio, temos agora uma situação bem mais hipotética, para não dizer fantasiosa: a venda de toda uma vila a pessoas bastante comuns norte-americanas - entre babás e policiais - para o prazer perverso deles.

\section{Questões de raça e de género}

A abertura do filme sugere que a vila é autossuficiente em termos de educação, possui cultura própria e não é adepta de nenhuma religião, pois a igreja matriz serve apenas como depósito de mesas escolares, além de outra tralha. Vemos que as pessoas vivem sua cultura não somente no funeral, que é liderado por um repentista e o filho da falecida - um educador, em vez de alguma autoridade religiosa -, mas também ao praticarem capoeira - arte marcial de origem africana -, justamente quando começam a se organizar para a autodefesa contra os invasores. A vila apresenta assim diversos tipos de pessoas com variadas agendas políticas. Plínio representa a educação, Lunga desde o início a resistência, Pacote a resistência velada e anárquica, e Domingas a questão da saúde. É feito uso de diferentes epistemologias, conhecimentos e tecnologias, algumas delas provendo das culturas afro-brasileira e ameríndia, e que participam na luta de resistência, ajudando para que a vila saia vitoriosa. As pessoas, por conhecerem a natureza, utilizam uma semente alucinógena para se protegerem psicologicamente, praticam capoeira para se fortalecerem fisicamente, e veneram os

\footnotetext{
${ }^{15}$ A protagonista de Aquarius (AQUARIUS, 2016) enfrenta a elite oligárquica, que trocou as fazendas pela especulação imobiliária e quer privá-la de seu apartamento para construir mais um condomínio de luxo. O filme não se interessa muito pela população dita humilde, que serve somente como coadjuvante. Mas, mesmo assim, o filme também foi interpretado como incitando resistência ao apresentar uma heroína que, embora enfrente a classe dominante, da qual de certa forma faz parte, na verdade luta apenas pela própria causa. No entanto, essa resistência, que termina com um ato de vingança - ela leva os cupins que estão infestando seu prédio para a imobiliária, já foi vista como razão para jubilo no contexto do impeachment de Dilma. Por outro lado, comparado com Terra em Transe, por exemplo, filme 50 anos mais velho, Aquarius se opõe à clássica conciliação entre classe dominante e média, mantendo, ao mesmo tempo, a ausência do povo, apontada por Jean-Claude Bernandet em seus estudos do cinema brasileiro.
} 
seus mortos e ancestrais. Na crítica muito apreciativa do The New York Times (DARGIS, 2020), a comunidade é considerada um quilombo, citando uma entrevista com os diretores que chamam Bacurau um "quilombo remix".

Contudo, apesar da valorização de elementos afro-brasileiros e indígenas, essa atitude remix participa no esvaziamento daquilo que o quilombismo representa historicamente e o que ele poderia significar como resistência na contemporaneidade. Desenvolvendo a ideia de resistência dos escravizados fugitivos que se uniram em quilombos durante o colonialismo - sendo o mais famoso o de Palmares, no século XVII, na então capitania de Pernambuco, ou seja, no estado onde também Bacurau é situado -, Abdias Nascimento (2019: 289-290) desenvolveu a ideia do quilombismo como uma ciência histórico-humanista cujo papel consistiria na recuperação da memória, cultura e conhecimento afro-brasileiros: "Quilombo não significa escravo fugitivo. Quilombo quer dizer reunião fraterna e livre, solidariedade, convivência, comunhão existencial. Repetimos que a sociedade quilombola representa uma etapa no progresso humano e sócio-político em termos de igualitarismo econômico." O que está em causa é o conhecimento e a resistência ao branqueamento e apagamento da cultura afrobrasileiro. Bacurau (2019) começa com a valorização do protagonismo negro, o professor Plínio e sua mãe Carmelita, possui os referidos elementos da cultura afrobrasileira, mas depois muda o rumo com a liderança da resistência por Lunga, de pele mais clara e associado ao cangaço. Há, assim, um certo aproveitamento da ideia do quilombismo, para depois ofuscá-la com a forma mais violenta de resistência dos cangaceiros. Assim, o sertão, classicamente visto como lugar de fanatismo religioso e violência ambígua na literatura, no cinema e nas artes plásticas, surge moderno e diverso, mas mestiço e não negro. Os sertanejos são retratados, ainda que robustos e resistentes, ao contrário das características atribuídas por Euclides da Cunha (2020: 6768), como nada "retrógrados" e "religiosos".

Consequentemente, o "remix", a mistura de elementos quilombolas com o cangaço faz com que o filme apresente o problema da comunidade não como uma questão racial, mas sobretudo como de classe - Tony Júnior faz o negócio pelo dinheiro e não como racista - e de gênero - os homens de gênero fluido são ultra violentos. $O$ problema do racismo é desconectado do Brasil e atribuído aos norte-americanos. Com efeito, a única cena que aborda racismo mostra que a supremacia branca é usada para humilhar os motoqueiros gaúchos. Esses querem ocupar a mesma posição que os gringos para sair de sua situação de subalternos, apesar de demonstrarem insegurança e certo complexo de inferioridade, o que contrasta com a soberbia com que lidam com o povo de Bacurau. Assim, os verdadeiros racistas do filme são os brancos americanos do Norte. Ao abordar o complexo de inferioridade dos brancos brasileiros, quem sofre 
racismo não é o povo de Bacurau, mas os euro-descendentes do Sul do pais. ${ }^{16}$ Mantêmse assim a tradição brasileira de não encarar o problema do racismo de frente, compreendido mais uma vez apenas como problema de classe, o que "subestima o papel dos fenômenos raciais e étnicos na análise de sociedades plurirraciais e multiétnicas [tendendo] a ofuscar o que há de específico na opressão racial" (HASENBALG, 1982: 78).

Subestimar o racismo é a primeira falha política do filme. A segunda falha consiste na maneira como substitui não só o racismo pelo problema de classe, mas também a liderança feminina pela masculina efeminada. Isso vem mascarado atrás da ideia de liberalismo sexual. O filme sugere o progressismo da vila através da já referida diversidade das orientações e práticas sexuais, além da também referida ausência de qualquer dogma religioso. No primeiro dia, antes de abrirem a feira e o museu e de conhecermos a igreja e a escola, chega um caminhão com três prostitutas, duas mulheres e um homem. A prática de sexo é visível, as prostitutas desfilam pela vila oferecendo seus corpos, transas acontecem de janela e porta abertas na luz do dia diversas vezes. Há uma mulher trans que vive com dois homens na entrada da vila e que serve também como informante sobre quem chega. Os rebeldes que organizarão a defesa da vila e farão boa parte da matança usando facões, são homens de gênero fluido, ou seja, não são nem trans nem travesti, mas, apesar de serem rebeldes armados e assim com sua masculinidade à mostra em gestos e comportamentos, pintam as unhas, usam apliques no cabelo e joias de gambiarra ou de ouro, lembrando a estética rebuscada dos cangaceiros.

Tudo isso para demonstrar que Bacurau não discrimina ninguém, que todos vivem sua identidade como querem. No entanto, a sexualidade feminina é tratada com menos apreço. Um primeiro exemplo em que isso se manifesta é o pequeno incidente no velório causado pela médica Domingas, que aparece bêbada, insultando a falecida.

\footnotetext{
${ }^{16}$ Há, ainda, outra ambiguidade em relação aos motoqueiros. Após os gringos terem assassinados os dois na reunião, por ordem superior através dos fones de ouvido que usam, é revelado o fato do homem ser assistente de desembargador, ou seja, trabalha no judiciário. Não fica claro se isto é uma crítica ao poder judicial eventualmente aliado aos vilões, possibilitando o seu trabalho, ou se indica uma investigação em curso. Não faz sentido, além de tornar os motoqueiros mais ambíguos e menos ruins.
} 


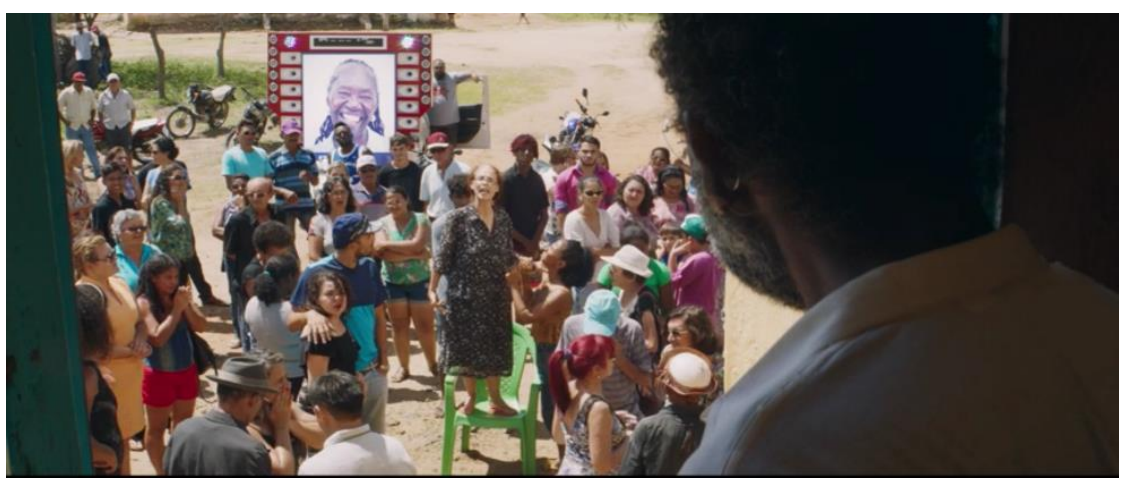

Figura 5: Domingas fazendo escândalo no velório de Carmelita. Fonte: Vitrine Produções.

Essa disputa de atenção com a morta não é esclarecida, e saberemos mais tarde que foram amigas quando jovens. Domingas se desculpará, mas não conseguirá ocupar o lugar vago de matriarca. Por quê? Os diretores criaram uma personagem bem ambígua com essa figura vivida por Sônia Braga. Apesar de possuir mais consciência e coragem quando enfrenta Tony Júnior, sua sexualidade é vista com suspeita. Ela é lésbica, mas sua companheira é mostrada tendo relações com um prostituto. No final há um beijo entre elas, mas é mostrado bem de longe. A homossexualidade feminina é de fato abordada com dificuldade por Mendonça Filho e Dornelles. Em vez da liderança feminina - também Teresa some na narrativa dando lugar a Pacote -, os machos cangaceiros assumirão, mesmo que de unhas pintadas. Dessa feita, é misturada mais uma luta política ao quilombismo e ao cangaço: a de pessoas de gênero fluido. A luta feminista ou lésbica, por sua vez, não parece ter lugar nesse remix masculinizado, para não dizer machista.

\section{Morte certa, biopoder, necropolítica}

A resistência do povoado surge porque a convivência pacífica dessa brava gente sertaneja é contrastada com o desejo de morte vivido pelos gringos e administrado pelo prefeito. Ou seja, a desumanização da qual Bacurau consegue se libertar em seu cotidiano está fatalmente à espreita. Sem que isso esteja associado à racialização das pessoas, o filme baseia seu conflito no tratamento dos descendentes dos escravizados pelo Estado e sua história como objetos de troca, agora mera carne para ser abatida. Mas os diretores, em vez de contextualizarem a história e a realidade interior e exterior da população afrodescendente atual, a usam para dramatizar e radicalizar a situação dos brasileiros médios do sertão e a morte certa deles. 
José Lingna Nafafé (2019) mostra como essa expressão, "a morte é certa", foi utilizada já no século XVII durante o primeiro movimento abolicionista da história. Não é portanto uma ideia nova, mas, mais importante ainda, uma ideia que fora pensada primeiro por um intelectual africano três séculos atrás. O príncipe angolano Lourenço da Silva Mendonça, cujo reino Ndongo havia sido destruído em Angola pelos conquistadores portugueses, foi primeiro exilado no Brasil e depois em Portugal, onde recebeu uma educação ocidental. Depois, tornou-se procurador internacional das Irmandades dos Pretos e foi até o Vaticano, abrindo um caso jurídico no qual advogou pela abolição da escravidão no Atlântico. Mendonça encabeçava um movimento ativista que englobava os Cristão Novos e os Ameríndios, e ganhou em primeira instância seu caso apresentado ao papa Inocêncio XI, no dia 6 de março de 1684. A carta de referência do Núncio português para liderar o primeiro movimento transatlântico de abolição trazia esse lema da morte certa e ela fez parte de sua argumentação, na qual ressaltou a violência e a miséria da existência humana dos escravizados. Enfatizava que, ao escravizar, os países colonialistas estavam quebrando todas as leis: natural, cívica, eclesiástica e divina. A certeza da morte removia dos escravizados, africanos e ameríndios, sua condição humana. É justamente essa condição - que igualmente quebra todas as leis existentes - que os diretores atribuem agora ao povoado de Bacurau, cujo prefeito do município faz valer novamente o poder colonial.

Ao dar essa importância à morte e ao combate dela, o filme inverte um de dois traços que Frederico Pernambuco de Mello (2018: 58) descreve como sendo típicos do sertão tardiamente feudal durante o cangaço: "o da indiferença do homem em face da morte e o de sua insensibilidade no trato com o sangue." Voltaremos para essa permanência da "insensibilidade no trato com o sangue" - vista como sendo resultado da atividade pecuária - e expressa no filme através de sua violência gráfica. Enquanto a "indiferença (...) em face da morte" - explicada através do fatalismo religioso - é substituída por um nova sensibilidade humanista e a resistência à morte certa em um contexto onde a religiosidade foi substituída por uma sociedade sem credo oficial cuja espiritualidade se expressa no culto aos mortos.

No atual contexto da pandemia da COVID-19, a ideia da poderosa ameaça pela morte como pano de fundo do filme ganhou, como a questão racial, novos contornos de atualidade. A construção dessa ideia de que a decisão sobre vida e morte está de fato nas mãos dos políticos é introduzida logo nos primeiros minutos, através de caixões que caíram de um caminhão, destinados, como saberemos depois, aos mortos que o jogo dos gringos irá causar. 


\section{rebeca}
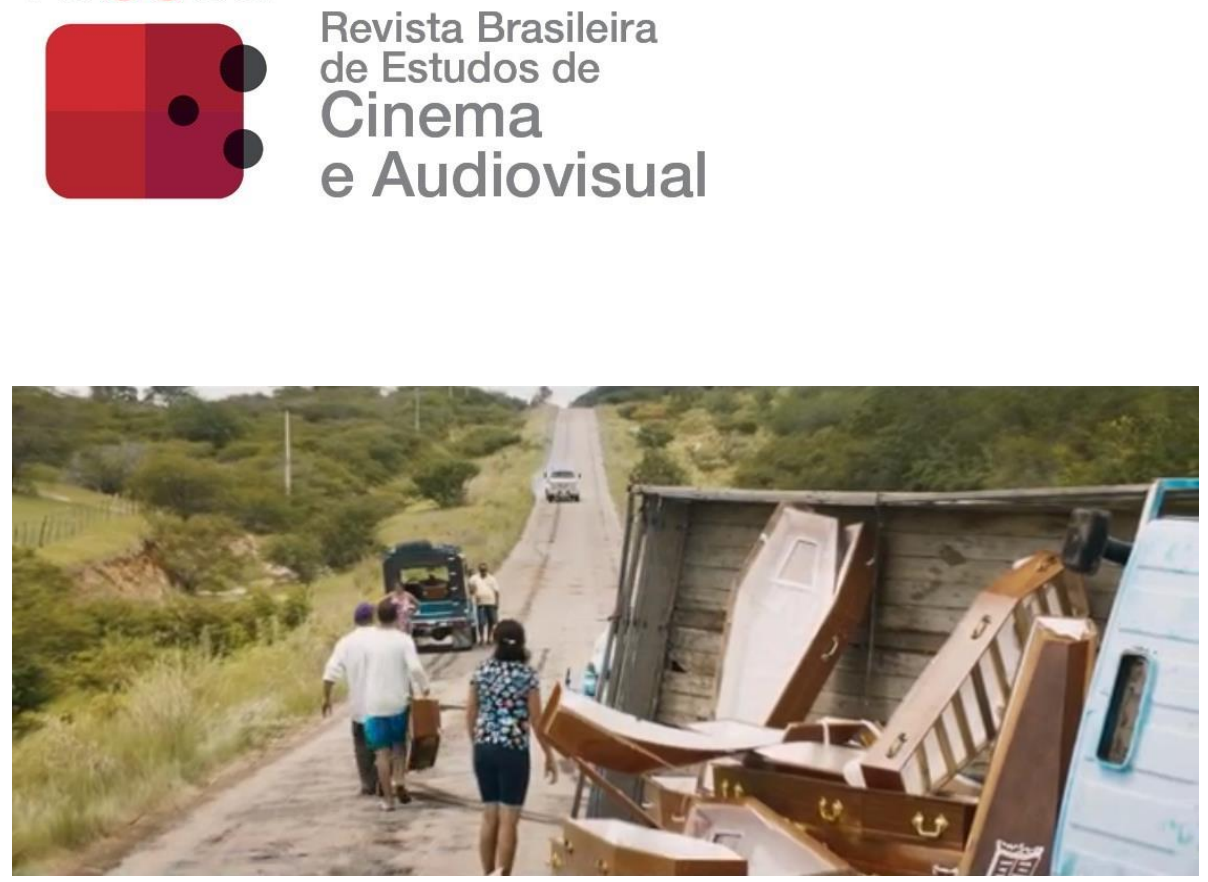

Figura 8: No caminho para Bacurau. Fonte: Vitrine Produções.

Depois do velório onde vemos o corpo de Carmelita sendo velado, diversos membros da comunidade morrem de forma violenta: primeiro dois jovens que descobrem os corpos assassinados de uma família e depois uma criança. Apesar da situação de ataque, há sempre tempo para homenagear os falecidos, destacando assim a humanidade do povoado, a importância que atribui aos seus e ao rito de passagem. No final do filme, todos os caixões que foram trazidos durante o ataque por um caminhão da prefeitura são expostos ao lado da igreja, sem que seja necessário seu uso pela população. Essa exposição do intento de morte realça o fato de que conseguiram quebrar o ciclo de violência por meio da resistência. Em outras palavras, o filme mostra que o poder é instável e que o povo pode vencer. É o discurso sedutor do filme: a resistência teve sucesso e a presença dos caixões que ficaram sem uso serve como lembrança e monumento do atentado à vida. $\mathrm{O}$ desejo de viver do povo ganhou sobre o desejo de matar dos turistas internacionais e dos políticos nacionais perversos. Curioso e importante observar que neste lugar supostamente laico a igreja ganha, assim, no final, lugar de destaque na comemoração. Além de ser o centro da cidade, muito sutilmente, e provavelmente inconscientemente, isso mobiliza uma série de ideias, tanto políticas como morais: a salvação dos justos, a vitória da vida sobre a morte no sentido da ressurreição prometida, e a absolvição do pecado de matar por uma causa justa. 


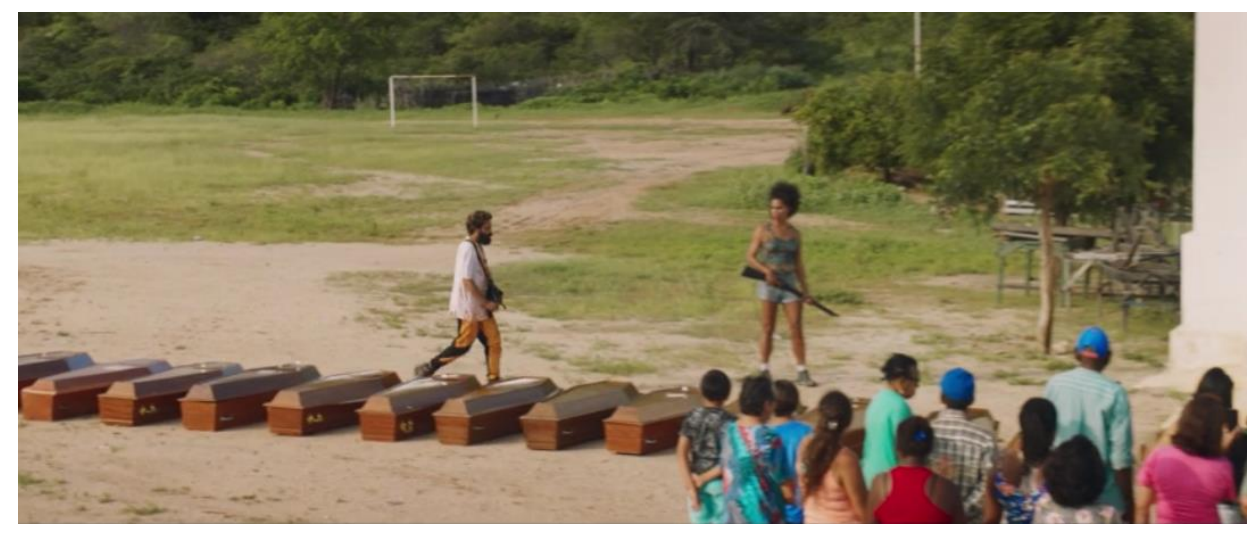

Figura 9: Exposição dos caixões não utilizados.

Fonte: Vitrine Produções.

A morte declarada ao povo, que não se cumpre, é resultado do jogo mortal dos gringos supremacistas. No triangulo do poder, eles são apontados como os mais agressivos. A escravidão, como já dito, não é abordada de forma direta. Como na cena final em frente à igreja, há somente indícios sutis que são, no entanto, suficientes para mobilizar o inconsciente coletivo brasileiro referente à sua história violenta. Entre esses indícios estão uma cena na qual o vilão principal norte-americano perambula pela fazenda onde estão hospedados, e outra no museu da vila que reúne relíquias várias da história do Nordeste, entre fotografias e artefatos. Ambos os espaços são explorados como territórios fantasmagóricos de uma história não contada, mas presente. São cenas muito significativas para assinalar para a escravidão, mas sem se comprometer muito, uma estratégia que Kleber Mendonça Filho usou em filmes anteriores por meio de personagens fantasmas negras. Em Bacurau (2019) a estratégia ganha ares de evasão porque, ao contrário de estratégias cinematográficas sofisticadas como nos filmes anteriores (cf. FERREIRA, 2017), o filme opta por uma linguagem bastante clássica. Além de referenciar o imaginário do cangaço e filmes de violência, não possui interlocução com o cinema de terror como em Aquarius (AQUARIUS, 2016) e O Som ao Redor (O SOM AO REDOR, 2012), que tinham uma densidade estética maior.

A fazenda, onde se organiza a invasão dos estadunidenses, volta a ser novamente a casa grande a partir da qual parte a violência contra os supostos Outros, baseada na supremacia branca personificada por eles, e só. Porém, ela é ressignificada como sendo agora responsabilidade norte-americana. Tem um momento em que o vilão toca em uma máquina de uma empresa com nome em inglês, atribuindo também por essa via a responsabilidade pela escravidão e o racismo ao mundo anglo-saxônico. 


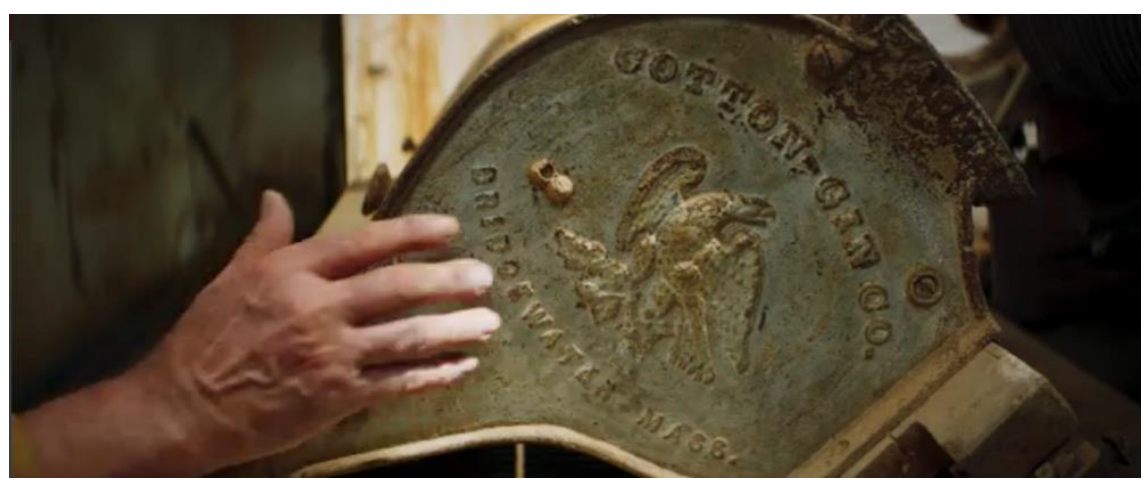

Figura 10: Máquina americana, na fazenda que serve como base dos gringos.

Fonte: Vitrine Produções.

Visto por olhos estrangeiros, sobretudo norte-americanos, o filme possui uma dimensão de diagnóstico interessante, sobretudo quando lembramos o acima referido assassinato de George Floyd. Mas isso talvez também indique que o filme foi pensado desde o início para um mercado global e não nacional, ou para uma mentalidade que não vê o racismo como problema nacional. Explica, mas não justifica que o racismo brasileiro é convenientemente substituídos pelo gringo.

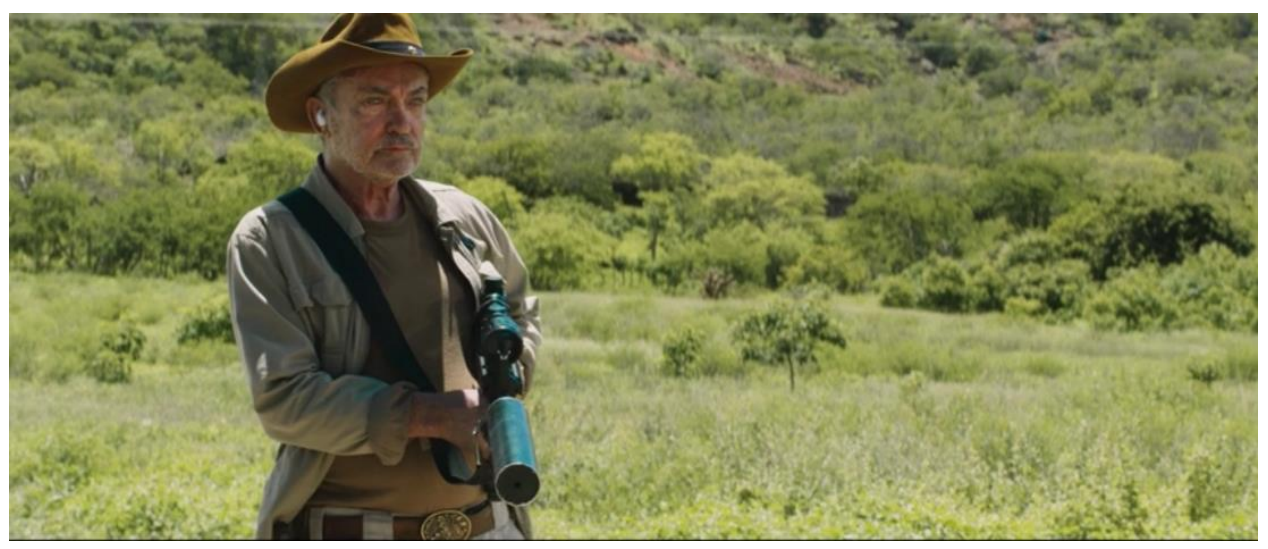

Figura 6: O chefe dos gringos a caminho da vila para matar a população.

Fonte: Vitrine Produções.

Na lógica do filme, não é por racismo que Tony Júnior vendeu a vila, mas por ganância e suposta legitimidade de exercer a violência de estado. Michel Foucault chamou esse tipo de violência famosamente de biopoder, querendo com esse conceito descrever, em 1976, a prática do estado moderno de ter o direito sobre a vida de seus 
súditos, mas também sobre a morte deles através do "direito de morte [que] tenderá a se deslocar ou, pelo menos, a se apoiar nas exigências de um poder que gere a vida e a se ordenar em função dos seus reclames." (FOUCAULT, 1999: 148) Mais recentemente, o filósofo camaronês Achille Mbembe (2016) ampliou o conceito foucauldiano, que considera insuficiente, e cunhou o conceito da "necropolítica". Com ele, procura revelar melhor como o estado soberano age na contemporaneidade, e como ele, ao contrário do modelo imaginado na filosofia do ocidente, ${ }^{17}$ que vislumbrava que os indivíduos se tornassem sujeitos, "instrumentalizou a existência humana e a destruição material de corpos humanos e populações" (MBEMBE, 2016: 125). O autor considera que hoje em dia a necropolítica não atinge somente a população afrodescendente, mas que o problema se generalizou. Através de Mbembe podemos perceber que há uma prática que vai bem além do discurso da filosofia da modernidade e que faz com que a população seja desprovida de seu "status político e reduzidos a seu corpo biológico" (2016: 125). ${ }^{18}$ Como comentamos, isso já era evidente nas primeiras lutas abolicionistas contra a escravidão no século XVII e possui raízes históricas que devem ser lembradas no contexto do Brasil.

No contexto latino-americano, essas observações também não são novas. Foram formuladas de forma mais crítica ao mundo ocidental por autores latinoamericanos. Aníbal Quijano (2006), Walter Mignolo e Rolando Vazquez (2013), e Rita Segato (2012), entre diversos outros, têm alertado que não vivemos em uma situação pós-colonial. O poder colonial é constantemente perpetuado e sua ferramenta fundamental foi sempre o racismo:

Com o tempo, os colonizadores codificaram como cor os traços fenotípicos dos colonizados e a assumiram como a característica emblemática da categoria racial. Essa codificação foi incialmente estabelecida, provavelmente na área britânico-americana. Os negros eram ali não apenas os explorados mais importantes, já que a parte principal da economia dependia de seu trabalho. Eram, sobretudo, a raça colonizada mais importante, já que os índios não formavam

\footnotetext{
${ }^{17}$ A ideia de Mbembe da filosofia ocidental talvez seja simpática demais se pensarmos na participação dela em diminuir os Outros, suas epistemologias e suas histórias.

${ }_{18}$ Vale lembrar que os autores europeus começaram a pensar a questão do racismo após o Holocausto dos judeus. Além de Foucault, que afirmou que o racismo de Estado fazia com que "a morte do outro, a morte da raça ruim, da raça inferior (ou do degenerado, ou do anormal) é o que vai deixar a vida em geral mais sadia; mais sadia e mais pura" (FOUCAULT, 1999: 305), Mbembe (2016) lembra Hannah Arendt, que foi a primeira a discutir isso após o extermínio judeu na Alemanha. Perante os campos de concentração, ela refletia sobre a "experiência demolidora da alteridade e sua afirmação que a política da raça está relacionada com a política da morte" (op. cit: 128).
} 
parte dessa sociedade colonial. Em consequência, os dominantes chamaram a si mesmo brancos. (QUIJANO, 2006) $)^{19}$

Escrevendo mais cedo ainda, em 1980, Abdias Nascimento - que não é conhecido pelos autores supracitados - entendia ser imperativo lembrar que o estado foi sempre violento contra os africanos e afrodescendentes no Brasil. Ou seja, que a racialização foi a base do colonialismo:

Para os africanos escravizados, assim como para os seus descendentes 'libertos', tanto o Estado colonial português quanto o Brasil - colônia, império e república - têm uma única e idêntica significação: um estado terror organizado contra eles. Um Estado por assim dizer natural em sua iniquidade fundamental, um Estado naturalmente ilegítimo, porque tem sido a cristalização político-social dos interesses exclusivos de um segmento elitista, cuja aspiração é atingir o status ário-europeu em estética racial, em padrão de cultura e civilização. (NASCIMENTO, 2019: 286)

O poder colonial contemporâneo, ou a necropolítica, travaram, de certa forma, uma guerra sem fim que prolonga a ideia da morte certa inaugurada pela escravidão. $E$ é essa guerra que Bacurau enfrenta, mas, como mencionado, sem abordar a sua base - o racismo - e sua história - a escravidão -, que delega aos norte-americanos. Sem mostrar de onde vem o mal além de ubicá-lo no político corrupto, não participa na decolonização da mentalidade escravocrata. Participa, pelo contrário, no apagamento dessa história, bem como no branqueamento, na comercialização e na folclorização da cultura afro-brasileira (GONZALEZ, 2020, NASCIMENTO, 2019), como veremos a seguir.

\section{Fantasias de vingança e vitória}

Quando os gringos começam a atacar Bacurau, a população está preparada para combater. Algumas mortes acontecem antes da resistência ser efetiva. Em termos narrativos, justificam a violenta resposta à perversidade dos gringos, que chegam a matar uma criança, ato até reprovado por alguns deles. Antes da carnificina em que a

\footnotetext{
${ }^{19}$ Mbembe (2016) compartilha desse pensamento ao dizer que a "raça" tem um lugar proeminente na racionalidade própria do biopoder mas não a identifica como motor senão como sombra: "Afinal de contas, mais do que o pensamento de classe (a ideologia que define história como uma luta econômica de classes), a raça foi a sombra sempre presente sobre o pensamento e a prática das políticas do Ocidente, especialmente quando se trata de imaginar a desumanidade de povos estrangeiros - ou dominá-los."
} 
população, que tomou um psicotrópico - parte da tecnologia ancestral, mas também estratégia para isentá-los da responsabilidade pela violência -, não só se defenderá mas também tomará vingança, há três cenas interessantes, porém parcialmente ambíguas. Mostram a superioridade da vila em termos éticos e também de conhecimento, mas fazem isso ou dentro da lógica de uma naturalização da violência, ou de forma apenas superficial.

$\mathrm{Na}$ primeira, um casal de idosos, ele negro e ela obesa, que cultiva plantas (responsáveis pelos psicotrópicos) e vive nu em seu sítio, é atacado por dois gringos, um homem e uma mulher. Despidos como eram os índios e os africanos escravizados, já mais velhos e assim aparentemente vulneráveis, não possuem apenas conhecimento ancestral das plantas, mas também instinto pelo perigo. Quando os gringos atacam, eles percebem sua presença e respondem com suas armas de fogo, matando o homem vemos ele depois no chão, de modo bem gráfico, com um enorme buraco na cabeça e sem cérebro - e ferindo a mulher, que não resistirá depois de levada à vila. A cena indica a tecnologia superior deles - a percepção de barulho - e cria imagens de excesso - as imagens dos corpos mutilados violentamente. $O$ excesso da imagem desses corpos atingidos está em acordo com a estética de excesso do filme, porém parece desnecessário dentro da narrativa. Há uma tendência na estética contemporânea de alertar que esse tipo de exagero do cinema popular não deve ser desprezado como cliché:

O filme de ação, prosperando na vulgaridade, carnalidade e apelo sensual, é um caso paradigmático de filme popular. É também manifestamente um exemplo de arte. Se quisermos entender toda a gama do que os filmes podem fazer, faremos bem em parar até mesmo um gênero desprezado como o chopsocky ou o festival de armas. Criar entretenimento fascinante a partir de dezenas de sutilezas bem avaliadas não é uma tarefa pequena. (BADIOU, 2013: 181)

No caso de Bacurau (2019), é claramente uma tentativa de usar estratégias do cinema de gênero no cinema autoral, o que fez com que tivesse, de fato, muito sucesso com o público. Não vamos entrar no mérito da estratégia estética de excesso, pois 0 nosso principal ponto de enfoque é a questão étnico-racial e até que ponto o filme a compreende como sendo o motor do poder colonial necropolítico, exercitado por Tony Júnior e os gringos.

A segunda cena convence mais e, vale observar, não precisa de excessos para tal. Domingas montou uma mesa para receber os gringos em um ato de resistência pacifica. Quem aparece é o mais perverso deles, o gringo natural da Alemanha. Ela 
oferece comida e bebida que são violentamente desprezados pelo homem através de um gesto de desconfiança. A cena reencena os primeiros contatos coloniais e, assim, a tentativa de uma abordagem amigável, baseada na hospitalidade de matriz indígena, solução essa impossível na guerra travada pelos supremacistas estrangeiros. Mostra, assim, uma questão chave que é sempre esquecida nas narrativas de colonização: que os forasteiros europeus que chegaram insalubres e famintos na costa brasileira (e antes nas costas africanas) foram recebidos de braços abertos. Essa hospitalidade fez com que os povos originários ficassem vulneráveis perante o interesse dos colonizadores de explorarem os recursos e as pessoas que encontraram. A reação do chefe dos gringos é de uma agressividade passiva: rejeita a comida, mas não mata Domingas, alegando seu código de ética do qual seus pares não compartilham - não matar mulheres e crianças. Vale ressaltar que o encontro o desestabiliza: ele agora matará seu próprio grupo em vez dos integrantes da vila.

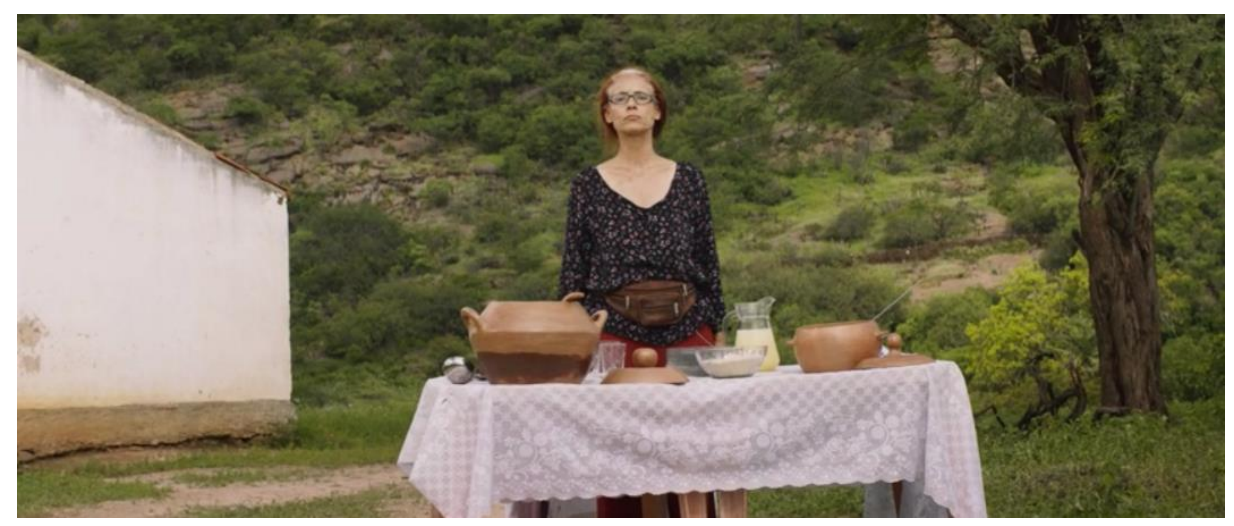

Figura 7: Domingas tentando apaziguar os gringos oferecendo comida.

Fonte: Vitrine Produções.

$\mathrm{Na}$ terceira cena vemos o chefe dos gringos após ele ter percebido que perderam. Ele coloca um revólver na boca, mas antes dele poder atirar, Carmelita aparece para ele. Surpreso com essa aparição - embora somente o espectador saiba que é sobrenatural - ele desiste e é preso. A ancestral voltou para garantir que justiça seja feita, pois ele será responsabilizado e enterrado em um ato simbólico que comentaremos a seguir.

O chefe dos gringos é de fato o único que sobrevive para sofrer uma humilhação pública em frente da igreja. Antes disso ocorre a invasão da vila, para a qual os bacurauenses estão preparados: cavaram um buraco que dá acesso a um espaço subterrâneo, tipo bunker, onde se escondem. Lunda está escondido no museu com seus 
homens, e a grande maioria da população, na escola. Todos estão armados com as armas de fogo e machetes do museu, relíquias de outras resistências: do cangaço. $\mathrm{Na}$ defesa, o protagonismo vai para Lunda, que fica banhado de sangue ao dar machetadas violentas cheio de raiva. É nesse momento que a resistência vira vingança, ao contrário da defesa do casal de idosos ou da tentativa de Domingas.

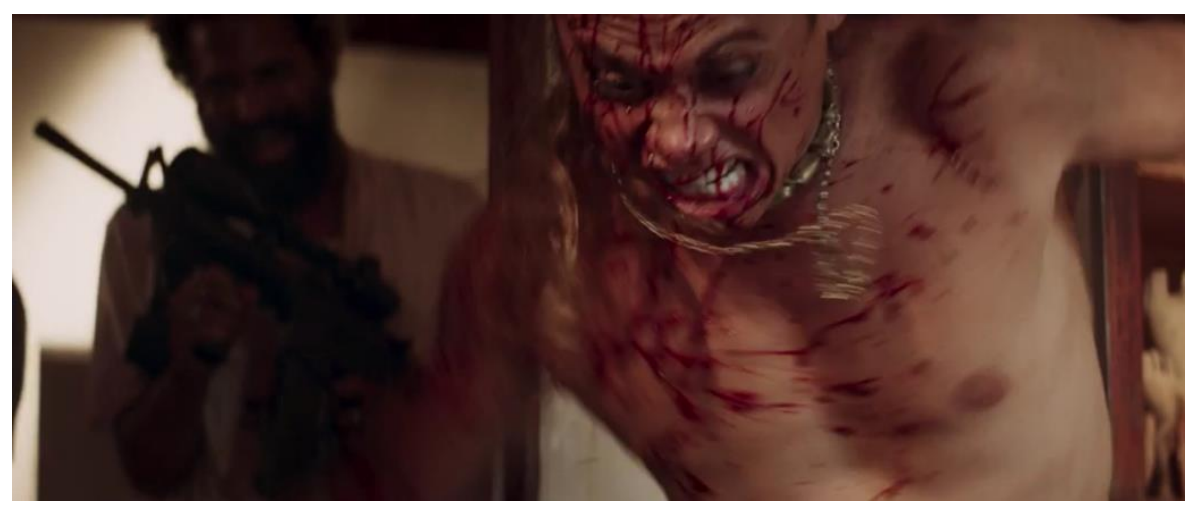

Figura 8: Lunda dando machetadas em um gringo já morto.

Fonte: Vitrine Produções.

Há consenso entre os psicólogos (GOLDNER et al., 2019; HOROVITZ, 2007) de que fantasias de vingança são importantes para a economia psíquica e que podem ser elemento central em um processo de cura ao oferecerem efeitos emocionais positivos. A vítima se sente bem ao adquirir um sentido de poder e controle perante 0 agressor. Além disso, essa fantasia fornece sentimento de prazer ao imaginar o outro sofrer sem que isso aconteça de fato. Participa, assim, na construção de uma subjetividade que vai além da vítima frágil e impotente. Porém, uma terapia costuma apontar a diferença entre fantasia e realidade, e, eventualmente, mostrar a futilidade das fantasias, incentivando a pessoa vingativa a procurar outras formas para construir sua autoestima, coerência e autocontrole para enfrentar sentimentos de humilhação, de injustiça e para ultrapassar eventos traumáticos.

Para o que serve a vingança violenta em Bacurau (2019)? Nos filmes que lidam com o cangaço, pelo menos no auge do gênero entre 1953-1965, era mostrada violência, porém de forma crítica, pois trataram muito mais do desejo de abandoná-lo do que de glorificá-lo; apesar de quase todos apresentarem a ideia de que os representantes do governo - os policiais, volantes e soldados - eram os verdadeiros vilões (cf. BERNARDET e RAMALHO JR, 2005). Depois, no Cinema Novo, "cuja estética de violência trilhava no viés da politização, a espetacularização da violência nos filmes 
de cangaço da Retomada, no que se insere o remake de $O$ Cangaceiro, adquire uma expressão de naturalidade cotidiana, colocando o espectador como um voyer do sofrimento alheio" (FREIRE, 2005: 71). Diríamos que aqui encontramos uma mistura do Cinema Novo e da Retomada: a ideia é a politização - a resistência -, mas ela passa pelo espetáculo - guiado pelo desejo de atingir o grande público que aprecia filmes de gênero com violência vingativa e seu prazer catártico.

Há de fato uma politização? Poderíamos dizer que Bacurau (2019) lida com violência porque o Brasil é um país violento. Franz Fanon (2006) já sabia que em situações de opressão é preciso pegar em armas. Já falamos detalhadamente que o cangaço foi um dos exemplos dessa violência como resposta. Mas o que isso diz sobre a capacidade de resistência da sociedade brasileira, convidada a se espelhar na comunidade fílmica que é brava contra os gringos e covarde quando deveria enfrentar o prefeito?

Vamos olhar para o final e sua economia de vingança. O gringo-alemão é preso e levado para o centro da vila, onde os habitantes estão expondo as cabeças dos outros gringos na já referida citação da fotografia das cabeças de Lampião, Maria Bonita e seus jagunços. Os caixões expostos permanecerão vazios, ou serão utilizados para os invasores e os mortos da vila. Em outras palavras, as imagens mostram que a necropolítica de Tony Júnior não vingou. De fato, o prefeito perdeu todo seu poder, que explorava através de seu cargo. No sentido de "o rei está nu", é banido, visivelmente reduzido à sua humilde condição humana, despojado de sua capacidade de vender para deixar matar. O filme opta por expô-lo, humilhá-lo, não matá-lo. Depois da violência espetacular, o ato é brando e algo folclórico. Acabou-se a vingança sangrenta, voltamos ao cordel.

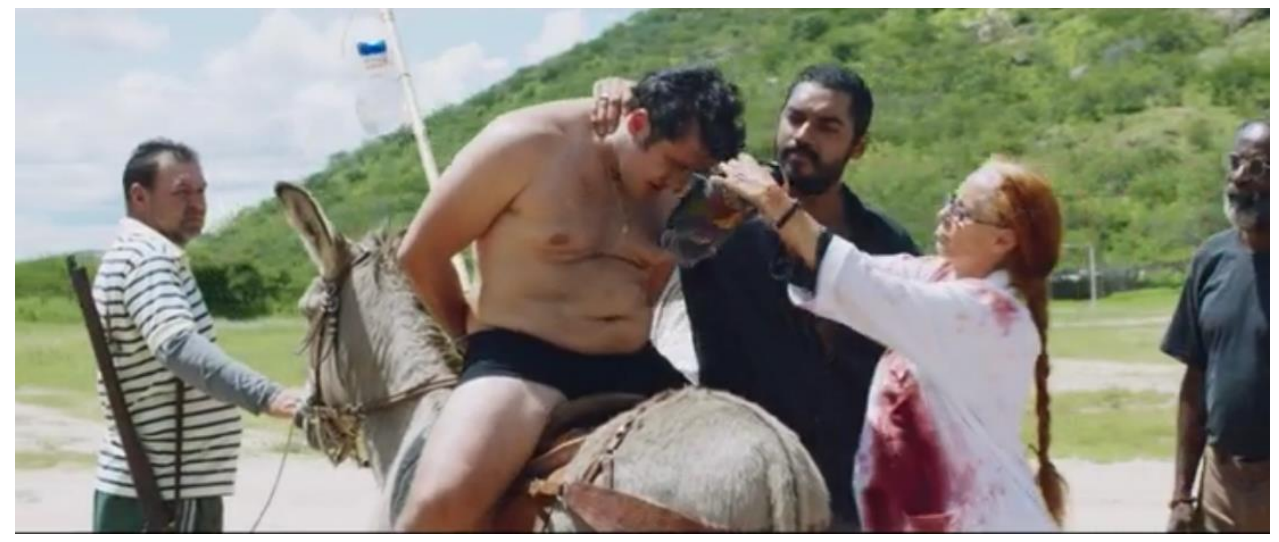

Figura 14: Tony Junior recebe máscara e será levado para o Sertão. Fonte: Vitrine Produções. 
O gringo-líder também não escapa, mas seu fim é a morte, mesmo que menos violenta: ele é enterrado vivo dentro do esconderijo da população. Seu grito, "isto só foi o começo", é abafado. Seu enterro é tão simbólico como a nudez do prefeito e as cabeças expostas. No entanto, deixa perceptível que a vingança se dirige apenas aos estrangeiros e, de forma violenta, apenas aos de baixo escalão. Os chefões, tanto nacional como internacional, não são despedaçados. A eles não se dirige a ira da população. São tratados politicamente. O filme inventa mais uma justificação: o gringochefe não matou ninguém da vila, somente aqueles que trabalham para o prefeito e alguns dos seus. Ambos são vistos como cínicos, mas não são diretamente responsabilizados pelos mortos de Bacurau. Os verdadeiros responsáveis são, assim, parcialmente isentados. Após a explosão de violência contra os gringos de baixo escalão, há um final moralista: eles são humilhados. Expostas as cabeças e enterrado vivo, para os gringos não haverá velório, suas mortes não serão celebradas como um rito de passagem. São punidos com a falta de dignidade de suas mortes e, consequentemente, de suas vidas.

\section{Conclusão}

Bacurau (2019) certamente possui uma narrativa de resistência. Mas há muitas ambiguidades em sua oposição à necropolítica do Estado brasileiro, o que faz com que não seja uma alegoria clara da situação atual. São várias as incongruências e problemas que apresenta. O filme não vincula a morte diretamente aos políticos nativos no país das milícias, dos altos índices de tudo o que é assassinato: de índios, jovens afro-brasileiros, mulheres, pessoas trans; o racismo e o desejo de matar vem de fora como se não fosse um assunto nacional; o filme isenta os chefões da responsabilidade de matar a população e se vinga apenas do baixo escalão, oferecendo um final dentro dos padrões do moralismo cristão para os verdadeiros responsáveis.

Em sua construção hiperbólica para vitimizar a vila e justificar sua resposta violenta e vingativa, os gringos são necessários porque servem um propósito: isentar o Brasil do racismo de acordo com os velhos mitos da democracia racial, da naturalização do racismo e das políticas de branqueamento devido à miscigenação. Assim, o filme perpetua a mentalidade brasileira de que somente os Estados Unidos realmente conhecem a supremacia branca e a segregação racial, pois aqui havia brandos costumes e luso-tropicalismo, ou seja, a inclinação para se misturar. Adocica assim a necropolítica brasileira, evitando mais uma vez de enxergar o racismo como causa do poder colonial ainda vigente. O prefeito, por mais absurdo que possa parecer, não é associado ao racismo que está em sua base. Ele é um traficante, um corrupto que 
"apenas" vende a população como eram vendidos os escravizados, ato naturalizado e esquecido depois da abolição. Sua punição é ser exposto; não precisa morrer porque nessa lógica não é tão ruim quanto os gringos, esses sim racistas e supremacistas.

Parte dessa lógica é a substituição da liderança negra pela dos rebeldes mestiços que defendem a população plurirracial. Há certamente uma valorização dos elementos afro-brasileiros e indígenas e uma visão de que sua tecnologia conhecimento da natureza e viver em harmonia com ela, respeito aos ancestrais e mortos, tentativa de mediação e solução pacifica através de hospitalidade - é superior à tecnologia de ponta dos supremacistas (apesar de participarem também desses aparelhos da modernidade). Mas em vez de valorizar o quilombismo e, assim, a luta histórica negra de forma plena, o filme recorre ao cangaço, que é livrado de sua ambiguidade histórica através da vitimização melodramática do povoado. Isso possibilita o uso da violência gráfica e a catarse infantil da fantasia de vingança. A substituição da liderança feminina pela liderança dos homens de gênero fluido ainda pega carona na luta política deles, mas desrespeitando a luta feminista e de mulheres lésbicas. No imaginário já estabelecido através do culto aos travestis em programas televisivos e esteticamente mais aceito do que mulheres emasculadas, a opção pelos homens efeminados possibilita aos diretores uma repaginada contemporânea e pop aos exóticos, perfumados e lindamente vestidos cangaceiros de outrora.

Consequentemente, Bacurau (2019) faz muitas concessões à nossa sociedade de consumo. Em termos gerais, a narrativa é filmada de fato, de forma muito convencional, próxima ao televisivo: além de utilizar referências aos filmes de cangaço e B americano, e à estética da violência de filmes cult, exotizar seus personagens masculinos ou inferiorizar os femininos tem muitos ingredientes para agradar o grande público. No entanto, não o faz para apresentar um assunto pouco palatável - a resistência -, porque sua estrutura melodramática e o esvaziamento histórico o tornam facilmente digerível. Seria mais correto dizer que usa uma estética palatável baseada no prazer da fantasia de vingança para iludir o público que esteja participando de um ato de resistência que, de fato, esconde mais uma vez aquilo que é de fato nada palatável - o racismo brasileiro.

Ignácio Araújo (2019a), da Folha de S. Paulo, compara Bacurau (2019) com outros filmes brasileiros contemporâneos, observando a sua pouco sofisticação política:

Temos muitas obras mais sutis do que "Bacurau", sem dúvida. "O que se Move", de Caetano Gotardo, "Branco Sai, Preto Fica", de Adirley Queirós, "Sinfonia da Necrópole", de Juliana Rojas, "Gabriel e a Montanha”, de Fellipe Barbosa. Todas obras bastante ignoradas pelo público e que não 
mereceram comentário algum de sociólogos, médicos, engenheiros, etc. (ARAÚJO, 2019)

Mesmo assim, Araújo considera como grande mérito do filme ter suscitado tanto debate no que diz respeito à sua agenda: contra o racismo, contra a supremacia do Sudeste sobre Nordeste, pela vontade de viver contra a vontade de matar. Um filme para o grande público, não hermético como os grandes clássicos do cinema brasileiro, por exemplo os de Glauber Rocha. São argumentos bonitos, mas a nossa análise mostra que na verdade o filme perpetua um pensamento simplificador e até falsificador acerca dessas questões.

Se ver um filme significa ver uma versão alternativa da nossa vida interior e da nossa realidade exterior (SEEL, 2013), ficou evidente que Bacurau (2019) ainda está longe de realmente reconhecer os mecanismos da necropolítica do país, sua base histórica e a relação ambígua com a violência que isso gerou, ao mesmo tempo que atende às fantasias de vingança dos que se sentem vitimizados e impotentes. Para quem é o filme? Para aqueles que acreditam que é preciso enterrar os supremacistas, que vêm de fora, e mandar no deserto os nossos políticos corruptos e folclóricos que estão cá dentro. O que o filme procura mobilizar? Uma fantasia de vingança que não chega a ser parte de um processo de cura porque evita, mais uma vez, enfrentar o fato de que a necropolítica está baseada no racismo interno. Os Estados Unidos estão acordando para essa realidade e isso, de fato, está provocando resistência e, com ela, violência. As imagens na televisão mostram melhor o biopoder de origem colonial e seu mecanismo do que Bacurau (2019), que o ofusca. Afinal, o filme alia o cinema de gênero ao cinema autoral para alimentar a fantasia de vingança sem apontar para outras formas para construir autoestima, coerência e autocontrole. Vem revestido de um sonho de resistência branca que precisaria de um embasamento mais sólido no racismo como motor do poder colonial para termos um verdadeiro diagnóstico da necropolítica reinante no Brasil e que possa decolonizar as nossas mentes por meio das discussões geridas. O sonho de resistência branca é resultado da história do Brasil, tanto quanto são as estratégias estéticas de Bacurau (2019). Demonstra que o país ainda é um lugar sobretudo de exportação - como indica a narrativa sobre a chegada dos gringos -, pois sua elite que produz cinema ainda não está suficientemente integrada ao sofrimento que resulta do colonialismo e do racismo que foi seu motor, no passado e no presente.

\section{Referências:}

ALMEIDA, Marco Antonio Bettine de; SANCHEZ, Livia. "Os negros na legislação educacional e educação formal no Brasil". Revista Eletrônica de Educação, v. 10, n. 2, 2016. p. 234-246. Disponível em: 
http://www.reveduc.ufscar.br/index.php/reveduc/article/download/1459/500. Acessado em: 30 de junho de 2020.

AQUARIUS. Direção: Kleber Mendonça Filho. Produção de Saïd Ben Said. Recife: Cinemascópio, 2016. DVD, $146 \mathrm{~min}$.

ARAÚJO, Inácio. "Réplica: Críticos dizem que 'Bacurau' é um filme de propaganda; e daí?". Folha de S. Paulo, 16 de setembro de 2019a. Disponível em: https://www1.folha.uol.com.br/ilustrada/2019/09/criticos-dizem-que-bacurau-e-umfilme-de-propaganda-e-dai.shtml. Acessado em: 2 de junho de 2020.

ARAÚJO, Inácio. "'Bacurau' é feito com raiva e troca a sutileza pelo ataque direto". Folha de S. Paulo, 24 de agosto de 2019b. Disponível em: https://www1.folha.uol.com.br/ilustrada/2019/08/bacurau-e-feito-com-raiva-e-troca-asutileza-pelo-ataque-direto.shtml_.Acessado em: 2 de junho de 2020.

ARISTÓTELES. Arte Poética. Disponível em: https://www.dominiopublico.gov.br/pesquisa/PesquisaObraForm.do?select_action=\&co _autor=144. Acessado em: 2 de junho de 2020.

BACURAU. Direção: Kleber Mendonça Filho, Juliano Dornelles. Produção de Emilie Lesclaux, Saïd Ben Saïd e Michel Merkt. Recife: SBS Productions, Globo Filmes, Cinemascópio, 2019. $132 \mathrm{~min}$.

BADIOU, Alain. Cinema. Cambridge e Malden: Polity Press, 2013.

BBC BRASIL. "Inquérito do STF sobre fake news: entenda as polêmicas da investigação que provoca atrito entre Bolsonaro e a Corte". BBC News Brasil, 27 de maio de 2020. Disponível em: https://www.bbc.com/portuguese/brasil-52824346. Acesso em: 2 de junho de 2020.

BENTES, Ivana. "Bacurau e a síntese do Brasil brutal". Cult, 29 de agosto de 2019. Disponível em: https://revistacult.uol.com.br/home/bacurau-kleber-mendonca-filho/. Acessado em: 2 de junho de 2020.

BERNARDET, Lucilia Ribeiro; RAMALHO JR, Francisco. "Cangaço - Da vontade de se sentir enquadrado". In: CAETANO, Maria do Rosário. Cangaço - O Nordestern no Cinema Brasileiro. Brasília: Avathar, 2005, p. 33-50.

CAETANO, Maria do Rosário. Cangaço - O Nordestern no Cinema Brasileiro. Brasília: Avathar, 2005.

CUNHA, Euclides da. Os Sertões. Jandira: Principis, 2020.

DARGIS, Manohla. “Bacurau' Review: Life and Death in a Small Brazilian Town”. The New York Times, 5 de fevereiro de 2020. Disponível em: https://www.nytimes.com/2020/03/05/movies/bacurau-review.html. Acessado em: 2 de junho de 2020.

FANON, Frantz. Os Condenados da Terra. Juiz de Fora: UFJF, 2006.

FERREIRA, Carolin Overhoff. "Refletindo sobre golpes duros e brandos: uma comparação de 'Aquarius' de Kleber Mendonça Filho e 'Terra em Transe' de Glauber Rocha". Rebeca, v.6, n.1, 2017, p. 1-43. Disponível em: https://rebeca.socine.org.br/1/article/view/412. Acessado em: 2 de junho de 2020. 
FOLHA DE S PAULO. "Veja falas preconceituosas de Bolsonaro e o que diz a lei sobre injúria e racismo". Folha de São Paulo, 26 de janeiro de 2020. Disponível em: https://www1.folha.uol.com.br/poder/2020/01/veja-falas-preconceituosas-de-bolsonaroe-o-que-diz-a-lei-sobre-injuria-e-racismo.shtml. Acesso em: 2 de junho de 2020.

FORLIN, Miguel. "A baixeza de Bacurau". Estado de São Paulo, 30 de agosto de 2019. Disponível em: https://estadodaarte.estadao.com.br/a-baixeza-de-bacurau/. Acessado em: 2 de junho de 2020.

FOUCAULT, Michel. História da Sexualidade, vol. I. Rio de Janeiro: A Vontade de Saber, 1999.

FOUCAULT, Michel. Em defesa da sociedade. São Paulo: Martins Fontes, 2000.

FREIRE, Alberto. "Remake de O Cangaceiro: nova versão, velhas leituras." In: CAETANO, Maria do Rosário. Cangaço - O Nordestern no Cinema Brasileiro. Brasília: Avathar, 2005, p. 69-74.

GOLDNER, Limor; LEV-WIESEL, Rachel; SIMON, Guy. "Revenge Fantasies After Experiencing Traumatic Events: Sex Differences". Frontier in Psychology, v.10, n.886, 2019, s.p. Disponível em: https://www.ncbi.nlm.nih.gov/pmc/articles/PMC6520653/. Acessado em: 2 de junho de 2020.

GONZALEZ, Lélia. Por um Feminismo Afro-Latino-Americano. Rio de Janeiro: Zahar, 2020.

HASENBALG, Carlos. "Raça, Classe e Mobilidade". In: GONZALEZ, Lélia; HASENBALG, Carlos. Lugar de negro. Rio de Janeiro: Marco Zero, 1982.

HOROWITZ, Mardi J. "Understanding and Ameliorating Revenge Fantasies in Psychotherapy". American Journal of Psychiatry, v.164, n.1, 2007, p. 24-27. Disponível em: https://ajp.psychiatryonline.org/doi/pdf/10.1176/ajp.2007.164.1.24. Acessado em: 2 de junho de 2020.

JUCÁ, Beatriz. "Silvero Pereira: 'Há uma revolução LGBT+ no sertão'”. El Pais, 27 de outubro de 2019.2 Disponível em: https://brasil.elpais.com/brasil/2019/09/23/cultura/1569265659_610072.html. Acessado em: 2 de junho de 2020 .

MAGNOLI, Demétrio. "'Bacurau' é testemunho da extinção de vida inteligente na esquerda brasileira". Folha de S. Paulo, 15 de setembro de 2019. https://www1.folha.uol.com.br/ilustrada/2019/09/bacurau-e-testemunho-da-extincao-devida-inteligente-na-esquerda-brasileira.shtml. Acessado: 2 de junho de 2020.

MBEMBE, Achille. "Necropolítica". Arte e Ensaios, n. 32, 2016, p. 123-151. Disponível em: $\quad$ https://www.procomum.org/wp-content/uploads/2019/04/necropolitica.pdf. Acessado em: 2 de junho de 2020.

MELLO, Frederico Pernambucano de. Apagando o Lampião - Vida e Morte do Rei do Cangaço. São Paulo: Global Editora, 2018.

MIGNOLO, Walter; VAZQUEZ, Rolando. "Decolonial AestheSis: Colonial Wounds/Decolonial Healings." Social Text Journal, 2013. Dísponível em 
https://socialtextjournal.org/periscope article/decolonial-aesthesis-colonialwoundsdecolonial-healings/. Acessado em: 2 de junho de 2020.

LINGNA NAFAFÉ, José. "Lourenço da Silva Mendonça: The first Anti-Slavery Activist?". Disponível em: https://mmppf.wordpress.com/2019/03/12/lourenco-da-silva-mendoncathe-first-anti-slavery-activist/. Acessado em: 13 de julho de 2020.

NASCIMENTO, Abdias. O genocídio do negro brasileiro. São Paulo: Perspectiva, 2016.

NASCIMENTO, Abdias do. O Quilombismo: Documentos de uma Militância PanAfricanista. São Paulo: Editora Perspectiva; Rio de Janeiro - RJ: Ipeafro, 2019.

NUNES, Rodrigo. "'Bacurau' não é sobre o presente, mas o futuro". El País, 05/10/2019. Disponível em: https://brasil.elpais.com/brasil/2019/10/05/cultura/1570306373_739263.html. Acesso em: 2 de junho de 2020.

ORICCHIO, Luiz Zanin. "O Cangaceiro Paradoxal - Corisco em 'Deus e o Diabo na Terra do Sol". In: CAETANO, Maria do Rosário. Cangaço - O Nordestern no Cinema Brasileiro. Brasília: Avathar, 2005, p. 51-54.

ORICCHIO, Luiz Zanin. "A força de Bacurau é simbolizar nossa falha trágica". 12 de setembro 2019. Disponível em: https://cultura.estadao.com.br/blogs/luiz-zanin/a-forcade-bacurau-e-simbolizar-nossa-falha-tragica/._Acessado em: 2 de junho de 2020.

PITANGA, Filippo. "Porque Bacurau foi o melhor filme de 2019". Carta Capital, 8 de janeiro de 2020. Disponível em: https://www.cartacapital.com.br/opiniao/porquebacurau-foi-o-melhor-filme-de-2019/. Acessado em: 2 de junho de 2020.

PRUDENTE, Eunice Aparecida de Jesus. "O negro na ordem jurídica brasileira." Disponível em: http://www.revistas.usp.br/rfdusp/article/viewFile/67119/69729. Acessado em: 30 de junho de 2020.

QUIJANO, Aníbal. Colonialidade do poder, eurocentrismo e América Latina. Buenos Aires: CLACSO, Consejo Latinoamericano de Ciencias Sociales, 2006.

SEEL, Martin. Die Künste des Kinos. Frankfurt: S. Fischer, 2013.

SEGATO, Rita. "Gênero e colonialidade: em busca de chaves de leitura e de um vocabulário estratégico descolonial". e-cadernos CES, n. 18, 2012, p. 106-131.

SOM ao redor, O. Direção e roteiro: Kleber Mendonça Filho. Produção: Emilie Lesclaux. Recife: Cinemascópio, 2012. 1 bobina cinematográfica (131 min), son., color., p\&b., DCP.

TELES, Edson. O Abismo na História. Ensaios sobre o Brasil em tempos de Comissão da Verdade. São Paulo: Alameda, 2018.

VASCONCELOS, Caê. "Número de homicídios de pessoas negras cresce $11,5 \%$ em onze anos; o dos demais cai 13\%". El País, 27/08/2020. Disponível em: https://brasil.elpais.com/brasil/2020-08-27/numero-de-homicidios-de-pessoas-negrascresce-115-em-onze-anos-o-dos-demais-cai-13.html. Acesso em: 2 de junho de 2020. 